\title{
Marine diatoms sustain growth of bivalves in a Mediterranean lagoon
}

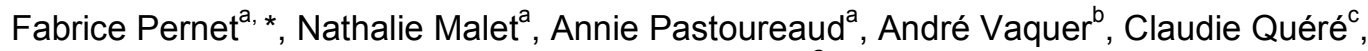 \\ Laurent Dubroca ${ }^{a}$
}

\author{
a Laboratoire Environnement Ressources du Languedoc Roussillon, Ifremer, Bd. Jean Monnet, 34200 Sète, \\ France \\ b Laboratoire Ecosystèmes Lagunaires, UMR CNRS/Ifremer/UM2/IRD Université Montpellier II, Place Eugène- \\ Bataillon, 34000 Montpellier, France \\ ${ }^{c}$ Laboratoire de Physiologie Fonctionnelle des Organismes Marins, Ifremer, Technopole de Brest-Iroise, 29280 \\ Plouzané, France
}

*: Corresponding author : Fabrice Pernet, email address : fabrice.pernet@ifremer.fr

\begin{abstract}
:
Carbon stable isotopes and fatty acids were measured in the suspended particulate organic matter (POM) of the Thau lagoon to study its qualitative temporal changes in relation to environmental factors and to identify the food sources of bivalves over a one-yr-cycle in relation to their growth. Reciprocally, the impact of shellfish farming on POM was also studied. Oysters and mussels were sampled and measured for biometry, stable isotopes and fatty acid composition. Water samples were collected at two sites, both inside and outside of the shellfish farming area, to determine concentrations in POM, chlorophyll a $(\mathrm{Chl} \mathrm{a)}$ and stable isotopes. Carbon isotopes and fatty acids in bivalves reflected seasonal changes in food sources, which varied consistently with the environment. Seasonal changes in $\delta^{13} \mathrm{C}$ and fatty acids in the bivalves suggested that dietary phytoplankton contribution varied according to season. Terrestrial organic matter and bacteria can contribute to the diet of bivalves during non-bloom periods. Mussels seemed to rely more on diatoms and less on terrestrial organic matter and bacteria than oysters did, particularly when phytoplankton biomass was low during the summer. Although one- and two-yr-old oysters showed similar $\delta^{13} \mathrm{C}$, their fatty acid dynamics differed slightly. Periods of high growth rate in bivalves were mainly fuelled by diatoms, thus highlighting the importance of seasonal blooms of microphytoplankton during the critical period of bivalve growth and gamete production. Although there was no significant effect of shellfish farms on $\mathrm{Chl} a$ and $\mathrm{POM} \delta^{13} \mathrm{C}$, consistent differences indicate that stable isotopes could be used successfully to investigate the effects of bivalve aquaculture.
\end{abstract}

\section{Highlights}

Carbon isotopes and fatty acids in bivalves reflected seasonal dietary changes. Terrestrial organic matter and bacteria can contribute to the diet of bivalves. Mussels and oysters showed significant differences in their fatty acids. $>$ Periods of high growth rate in bivalves were mainly fuelled by diatoms. Stable isotopes allow investigating the effects of bivalve aquaculture.

Keywords: Aquaculture ; Bivalve ; Competition ; Feeding ecology ; Growth ; Trophic markers 


\section{Introduction}

Bivalves derive nutrients from a variety of particulate material, including phytoplankton, resuspended benthic microalgae, detritus from a mixture of sources, bacteria and microheterotrophs (e.g., Dupuy et al., 2000b; Kreeger and Newell, 2001; Trottet et al., 2008b). However, it is generally considered that bivalves are herbivorous and that phytoplankton is their primary source of food, as growth and reproductive activities of bivalves follow the annual cycle of phytoplankton biomass (Kang et al., 2006). In temperate coastal areas of the Mediterranean climate, rainfall and nutrient input are concentrated in fall and winter, and phytoplankton biomass subsequently peaks in spring, when bivalves undergo rapid growth and gonad development.

In the Mediterranean Thau Lagoon, an important European bivalve farming area, growth rates of the oyster Crassostrea gigas are among the highest in France, although chlorophyll a concentration is low compared with other coastal ecosystems (Gangnery et al., 2003). It was hypothesized that picoplankton and protists could explain such paradoxical oyster growth. However, a short-term experimental assimilation study showed that diatoms were the main food source for oysters (Dupuy et al., 2000b). Nevertheless, conclusions of this study are tempered by the fact that pico- and nanophytoplankton abundances were not as high as expected, whereas the high abundance of large diatoms was rather unusual (Dupuy et al., 2000b).

Thau lagoon also traditionally supports a high biomass of cultivated mussel Mytilus galloprovincialis (Gangnery et al., 2004), which is now found in increasing numbers due to the recent mass mortality of young oysters (Pernet et al., 2010a). Although mussels, like other bivalves, are generally considered as herbivorous animals, recent studies conducted into a Canadian lagoon show that heterotrophic plankton is a dominant food source for $M$. edulis (Trottet et al., 2008a; b). To understand their relative importance, therefore, the relative contribution of each food type to the diet of oysters and mussels in the Thau lagoon needs to be further investigated in the field over a long time period that covers seasonal fluctuations in availability of different food types.

One concern about intense bivalve farming in small and confined areas such as the Thau lagoon is the risk of attaining the carrying capacity of the system, i.e., the maximum bivalve biomass that can be supported without affecting future productivity and integrity of the ecosystem (Dame and Prins, 1997). Indeed, dense communities of bivalves generally limit phytoplankton biomass and stimulate primary production by increasing nutrient recycling though bivalve excretion (Souchu et al., 2001). Impact studies of bivalve aquaculture are generally based on phytoplankton biomass, but these would be meaningless if a large proportion of what the animals consumed was indeed bacteria, detritus and heterotrophic plankton rather than phytoplankton. To our knowledge, only a few papers have investigated the impact of bivalve farming both from a quantitative (phytoplankton biomass) and a qualitative (diet composition) standpoint (Trottet et al., 2008a).

In many coastal areas, stable isotope analysis has been used successfully to study the trophic links from primary producers to higher trophic levels, indicating different utilization of food sources by benthic and pelagic invertebrates (Fry, 2007). Indeed, stable isotopes in consumers provide time-integrated information on food sources, averaging the natural environment variability in dietary components. For example, the $\delta^{13} \mathrm{C}$ values of consumers reflect the $\delta^{13} \mathrm{C}$ values of their diet with only small changes, generally within $1 \%$. Stable isotopes have been used to trace the food sources of benthic bivalve molluscs in a number of different types of coastal ecosystems (Allan et al., 2010; Dang et al., 2009; Dubois et al., 2007; Herman et al., 2000; Kang et al., 1999; Kang et al., 2006; Kharlamenko et al., 2001; 
Lebreton et al., 2011; Lefebvre et al., 2009; Lorrain et al., 2002; Malet et al., 2007; MarinLeal et al., 2008; Page and Lastra, 2003; Riera and Richard, 1997; Rossi et al., 2004).

Lipid markers also provide complementary information on the type and quality of resources assimilated by animals (Dalsgaard et al., 2003). Marine bacteria, diatoms, dinoflagellates, terrestrial inputs and vascular plants show different combinations of specific fatty acids. Given that fatty acids are incorporated largely unaltered into the reserve lipids of primary consumers like oysters and mussels, they generally reflect the fatty acid profiles of the food consumed and could therefore reveal useful information about trophic sources (Allan et al., 2010; Dalsgaard et al., 2003; Delaunay et al., 1993; Kharlamenko et al., 2001; Lebreton et al., 2011; Soudant et al., 1999). When used together, fatty acid and stable isotope techniques show promise for resolving the trophic ecology of complex aquatic ecosystems.

Stable isotopes and fatty acid signatures are widely used to investigate the dynamics and sources of particulate organic matter (POM) in aquatic ecosystems (Cloern et al., 2002; Galois et al., 1996; Malet et al., 2008). For example, Malet et al. (2008) showed marked seasonal variations in the contribution of terrestrial inputs from rivers, neritic phytoplankton and resuspended microphytobenthos, and periodic inputs from intertidal meadows to the POM in an oyster farming bay. Although coastal lagoons are among the most productive and complex areas of the coastal zone, these aspects of their ecology have been much less studied than those of estuaries and salt marshes (Carlier et al., 2007; Vizzini and Mazzola, 2003).

The objectives of this study are to use stable isotope and fatty acid signatures (1) to determine the temporal variability of suspended POM in the Thau lagoon in relation to environmental parameters, (2) to identify the food sources of oysters $C$. gigas and mussels M. galloprovincialis over a one-year cycle in relation to their growth parameters, and (3) to examine the impact of bivalve farming on trophic resources.

\section{Materials and methods}

\subsection{Study area}

The Mediterranean Thau lagoon is an oyster farming area that accounts for about $10 \%$ of French Pacific oyster production. Growth rates are among the highest in France for this species (Gangnery et al., 2003). The Thau lagoon is $19 \mathrm{~km}$ long, $4.5 \mathrm{~km}$ wide and $5 \mathrm{~m}$ deep on average (Fig. 1). Shellfish are cultured in 3 areas of the lagoon, namely Bouzigues, Mèze and Marseillan, which together cover about $20 \%$ of the total surface. The lagoon is almost closed, with only narrow connections to the Mediterranean Sea through the Sète channel and other small connections that are negligible in terms of water exchange. The catchment area of the lagoon is about $300 \mathrm{~km}^{2}$, including land used for agriculture, industrial activities and urban development.

\subsection{Environment}

Temperature and salinity were recorded every $10 \mathrm{~min}$ using one autonomous CTD multiparameter recorder (NKE instrumentation, Hennebont, France) deployed at Marseillan in the farming area of the lagoon (Fig. 1, dotted circle). Phytoplankton concentrations (cell $\mathrm{L}^{-1}$ ) were measured by Ifremer's REPHY network (Phytoplankton and Phycotoxin Monitoring Network) at Marseillan, inside the bivalve farming area. Samples for phytoplankton identification were preserved with Lugol's solution $\left(1 \mathrm{~mL} \mathrm{~L}^{-1}\right)$. Ten $\mathrm{mL}$ were placed in a phytoplankton chamber for at least $6 \mathrm{~h}$ for sedimentation, then identified and counted using an inverted microscope (Olympus IMT 2, Olympus, Japan), at 40x. Most 
species were aggregated at their genus level. Daily rainfall, measured at the weather station in Sète, was obtained from the Météo France database.

\subsection{Sample collection}

\subsubsection{Seston}

Water samples were collected at Bouzigues and Marseillan, both inside and outside the bivalve farming area, 29 times between 2 March 2009 and 7 April 2010. About $5 \mathrm{~L}$ of water was collected and pre-filtered through a $200 \mu \mathrm{m}$ screen to remove any large zooplankton or algal debris. Total particulate matter (TPM) was determined after samples had been filtered through pre-combusted, pre-weighed Whatman GF/C filters and dried for $24 \mathrm{~h}$ at $60{ }^{\circ} \mathrm{C}$. Particulate inorganic matter (PIM) was then determined after the filters had been combusted for $4 \mathrm{~h}$ at $450{ }^{\circ} \mathrm{C}$. These parameters were determined in triplicate. Chlorophyll a (Chl a) was extracted from $50 \mathrm{~mL}$ of seawater filtered on Whatman GF/F filters in acetone $90 \%$ for $24 \mathrm{~h}$ in the dark, and its concentration was determined using a Perkin-Elmer spectrofluorometer LS50B (Neveux and Lantoine, 1993). Two final samples of $1 \mathrm{~L}$ of water were filtered onto precombusted Whatman GF/C filters and frozen at $-80{ }^{\circ} \mathrm{C}$ for subsequent $\mathrm{C}$ and $\mathrm{N}$ stable isotope and fatty acid analyses.

\subsubsection{Other sources of organic matter}

Briefly, water samples from the three main rivers flowing into the Thau lagoon (Veine, Pallas and Canal du Midi, $n=2-3$ samples for each river) and from the Mediterranean Sea $(n=5$ samples), were filtered onto precombusted Whatman GF/C filters. Samples of the marine plant (Zostera marina, $n=4$ samples of leaf without biofilm), microphytobenthos $(n=3$ samples collected by scrapping the periphyton on ropes suspended in the water column) and sediments ( $n=4$ samples collected by scrapping the top $5 \mathrm{~mm}$ sediment surface) were collected and frozen at $-80^{\circ} \mathrm{C}$ for subsequent stable isotope and fatty acid analyses.

\subsubsection{Animals}

One- and two-yr-old oysters (Crassostrea gigas) were initially collected in the field (i.e., wild seed) at Arcachon in 2008 and 2007 respectively, whereas one-yr-old mussels (Mytilus galloprovincialis) were collected in the field in the Thau lagoon in 2008. Two-yr-old mussels were not considered in this study as they are usually harvested before they reach this age in Thau lagoon. Oysters and mussels were transferred to the Ifremer Laboratoire Environnement Ressources en Languedoc-Roussillon, Sète, France $\left(43^{\circ} 23^{\prime} \mathrm{N}, 3^{\circ} 4^{\prime} \mathrm{E}\right.$; Fig. 1) on 12 March 2009. Upon arrival at Ifremer Sète, 100 individuals from each species and age class were measured and weighed for initial characterization. Overall, one-yr-old oysters and mussels were similar size: $27.2 \pm 5.5 \mathrm{~mm}$ and $25.5 \pm 4.4 \mathrm{~mm}$ shell length, respectively, whereas two-yr-old oysters were $66.6 \pm 5.5 \mathrm{~mm}$ shell length.

In the Thau lagoon, small oysters are cultivated in pearl nets fixed to ropes suspended in the water column from fixed rearing structures (called "tables"). Oysters that are large enough (i.e., shell length $>3$ to $4 \mathrm{~cm}$ ) are then either cemented directly onto ropes or placed in Australian nets, which are then suspended in the water column from culture tables. Mussels are placed in tubular plastic nets, which are hung from tables by ropes. In our experiment, 2250 one-yr-old oysters and mussels were equally distributed between 9 pearl nets for each species (initial density $=250$ individuals per pearl net). Groups of 3 pearl nets were attached together on a single 'rope', so that there were 3 ropes used for each species. Rope length 
was $6 \mathrm{~m}$ and pearl nets were deployed at 1, 2, and $3 \mathrm{~m}$ depth. Two-yr-old oysters were distributed into 9 Australian nets (initial density $=100$ individuals per net). Australian nets were deployed at $2 \mathrm{~m}$ depth. The ropes were hung from the Ifremer culture table at Marseillan on 14 March (Fig. 1).

Oysters and mussels were sampled for biometrical parameters and stable isotope and fatty acid composition of soft tissues between 30 March 2009 and 7 April 2010. The biometrical parameters measured were tissue and shell dry masses, and shell length. For one-yr-old animals, dry masses were measured on three pooled individuals for each rope (one oyster per pearl net). For two-yr-old animals, dry masses were measured on 18 individuals collected from 6 Australian nets. Tissues and shells for dry mass measurements were placed in preweighed aluminium cups, dried for $72 \mathrm{~h}$ at $60^{\circ} \mathrm{C}$ and weighed on a Mettler precision balance (Mettler-Toledo, Viroflay, France). Shell length was measured individually on a sub-sample of 25 animals from each pearl net and Australian net. Shell length, defined as the greatest anteroposterior dimension, was measured with a digital calliper (Mitutoyo, Paris, France).

\subsection{Stable isotope analyses}

Three oysters from each age class were collected from three different ropes and starved for $24 \mathrm{~h}$ in $0.7 \mu \mathrm{m}$ filtered seawater. These oysters were then carefully dissected in order to separate the adductor muscle, digestive gland and gonads from the gills and mantle, as previously described in Malet et al. (2007). Oyster tissues were quickly rinsed in $10 \% \mathrm{v}: \mathrm{v}$ $\mathrm{HCl}$, and then twice in de-ionised water. Digestive gland and muscle were freeze-dried and ground thoroughly to a fine powder. Water sample filters were acidified with $2 \mathrm{~N} \mathrm{HCl}$ acid vapour in a glass desiccator for $4 \mathrm{~h}$ at room temperature in order to remove carbonates, and then kept frozen at $-20^{\circ} \mathrm{C}$ until analysis. Samples of Zostera marina were quickly rinsed in 10 $\% \mathrm{v}: \mathrm{v} \mathrm{HCl}$ and then twice in de-ionised water. Sediments were acidified with $1 \mathrm{ml}$ of $2 \mathrm{~N} \mathrm{HCl}$ for $100 \mathrm{mg}$. Particulate organic matter (POM) was scraped from the fibreglass filters. Carbon and nitrogen isotope ratios of the oyster tissues $(n=3)$, POM and other sources of organic matter were measured by continuous flow isotope ratio mass spectrometry (CFIRMS) analysis using an IsoPrime stable isotope mass spectrometer (Micromass) interfaced to an elemental analyser EuroEA3024-IRMS (Eurovector). The analytical precision of 10 consecutive measurements was $<0.15 \%$ for both $\mathrm{N}$ and $\mathrm{C}$ isotope ratios. Data are expressed in the standard $\delta$ notation as parts per thousand (\%o) relative to Peedee Belemnite Limestone (PDB) and atmospheric $\mathrm{N}_{2}$ for carbon and nitrogen, respectively. The acetanilide laboratory standard was calibrated using certified graphite and IAEA-N2 (ammonium sulphate) as a reference material. The stable isotopic ratio is reported as $\delta^{A} X=$ ( $\left.\left.R_{\text {sample }} / R_{\text {standard }}\right)-1\right] 10^{3}(\%)$, where $\mathrm{A}$ is the atomic mass of the heavy stable isotope of the element $X$, and $R={ }^{13} \mathrm{C} /{ }^{12} \mathrm{C}$ for carbon and ${ }^{15} \mathrm{~N} /{ }^{14} \mathrm{~N}$ for nitrogen, respectively. For the purpose of this study, only the $\delta^{13} \mathrm{C}$ in the POM and oyster digestive gland are presented. Values of $\delta^{13} \mathrm{C}$ in digestive gland generally mirrored those of the diet more closely than did those of the muscle (Lorrain et al., 2002). Also, nitrogen isotopic analyses did not offer much insight for our study and are therefore not presented. Due to logistical limitation, stable isotope analyses were conducted on oysters only.

\subsection{Fatty acid analyses}

From each rope, three one-yr-old oysters or mussels (one animal per pearl net) were collected, pooled together and stored at $-80{ }^{\circ} \mathrm{C}$ for fatty acid analyses. Two-yr-old oysters were large enough to be individually sampled, so that one animal per Australian net was collected in 3 different nets. Each animal sample ( $n=3$ for each species and age class) was ground with a MM 200 mixer mill (Retsch, Eragny sur Oise, France) at $-180{ }^{\circ} \mathrm{C}$. Aliquots $(300$ $\mathrm{mg})$ were placed in amber glass vials filled with $3 \mathrm{~mL}$ chloroform-methanol $(2: 1 \mathrm{v} / \mathrm{v})$ for further lipid analysis. An aliquot of the sample $\left(\mathrm{CHCl}_{3}-\mathrm{MeOH}\right.$ mixture) was evaporated to 
dryness and lipids recovered with three $500 \mathrm{~mL}$ washings of $\mathrm{CHCl}_{3}-\mathrm{MeOH}(98: 2 \mathrm{v} / \mathrm{v})$. The lipids were placed at the top of a silica gel microcolumn $(30 \times 5 \mathrm{~mm}$ internal diameter; Kieselgel; 70-230 mesh [Merck, Lyon, France]; previously heated to $450{ }^{\circ} \mathrm{C}$ and deactivated with $5 \%$ water). The neutral lipids were eluted with $10 \mathrm{~mL} \mathrm{CHCl}{ }_{3}-\mathrm{MeOH}$ mixture $(98: 2 \mathrm{v} / \mathrm{v})$. The polar lipids were recovered with $15 \mathrm{~mL}$ methanol. Water sample filters and other sources of organic matter (microphytobenthos and sediment) were placed in amber glass vials filled with $3 \mathrm{~mL}$ of chloroform-methanol $(2: 1 \mathrm{v} / \mathrm{v})$ and sonicated for $10 \mathrm{~min}$ in a water-bath prior to lipid extraction following Folch (1957). Samples of marine plants were ground with a $7 \mathrm{~mL}$ Tenbroeck potter homogenizer in chloroform-methanol $(2: 1 \mathrm{v} / \mathrm{v})$ prior to lipid extraction following Folch (1957). A known amount of 23:0 fatty acid was added as an internal standard to both neutral and polar fractions of the animal samples and to the total lipids of samples of water and other sources of organic matter. Lipids were transesterified with $10 \mathrm{wt} \%$ boron trifluoride-methanol (Metcalfe and Schmitz, 1961) and analysed according to the method described by Marty et al. (1992). The fatty acid methyl esters (FAME) were analysed in a gas chromatograph with an on-column injector, a DB-Wax $(30 \mathrm{~m} \times 0.25 \mathrm{~mm} ; 0.25 \mu \mathrm{m}$ film thickness) capillary column and a flame ionization detector. Hydrogen was used as the carrier gas. The fatty acids were identified by comparing their retention times with those of standards. Only the fatty acids in the neutral lipids of the animals are presented here since neutral lipids reflect the fatty acid profiles of food consumed and could reveal information about trophic sources, whereas fatty acids in the polar lipids are less sensitive to dietary changes (Dalsgaard et al., 2003). Additionally, water samples showed a very low level of fatty acids, with unusual profiles and no changes over time, likely reflecting unknown methodological issues. Therefore, to avoid confusion, the results of these analyses were not included in this paper.

\subsection{Statistical analyses}

\subsubsection{Analyses of variance}

Three-way split-plot analyses of variance (ANOVA) were conducted to determine differences in POM, Chl a, stable isotope and fatty acid composition of water samples according to sites (fixed between-subjects factor with 2 levels: Marseillan vs. Bouzigues), locations (fixed between-subjects factor with 2 levels: inside vs. outside of the bivalve farming area) and sampling date (random factor with 29 levels of repeated measurements between 2 March 2009 and 7 April 2010) and their interactions (Table 1). The interactions between site $x$ location and site $\times$ location $\times$ date were used as error terms in the analysis due to the lack of replication at these levels.

Two-way split-plot ANOVAs were conducted to determine differences in biometrical parameters, stable isotopes and selected fatty acid combinations (see below) in the soft tissues of bivalves according to species and age class (fixed between-subjects factor with 3 levels for biometry and fatty acids [oysters: one- and two-yr-old, mussels: one-yr-old only] and 2 levels only for stable isotopes [oysters: one- and two-yr-old]) and sampling date (random factor with 15 levels of repeated measurements between 30 March 2009 and 7 April 2010) and their mutual interactions (Table 2). The unit of replication was the rope from which animals were taken. When differences between the species and age classes were detected without an interaction with sampling date (main effect), planned comparisons between group means were made (Table 2).

In both ANOVAs, the repeated option was applied to the term 'sampling date' to take into account temporal dependence. Significant differences between all possible combinations of sample means were assessed using least-square means multiple comparisons tests $(\alpha=$ 
0.05). Homogeneity of variance-covariance matrices was graphically assessed. All ANOVAs were performed with SAS 9.0 (SAS Institute Inc., Cary, NC, USA).

\subsubsection{Regression analyses}

Regression models were used to examine the relationships among variables measured in the water samples (POM, Chl $a$, and $\delta^{13} \mathrm{C}$ ) and between $\delta^{13} \mathrm{C}$ in water samples and in oyster tissues. Regression models were also used to assess the relationship between biometrical parameters (shell mass and length) and time for one- and two-yr-old oysters and one-yr-old mussels. Linear and polynomial regression models were tested. Normality of residuals was tested using Shapiro-Wilk, and homoscedasticity of variances was examined graphically. A significance threshold of 0.05 was adopted for all regression tests. All regression analyses were carried out using SigmaPlot 11.0 (Systat Software Inc., Chicago, IL, USA) and SPSS 15.0 (SPSS Inc., Somers, NY, USA).

\subsubsection{Multivariate analyses}

Time series of fatty acids for each species and age class were associated using a hierarchical clustering method based on the Euclidian distance and Ward's linkage methods (Ward, 1963). The estimation of the optimal number of clusters in the resulting dendrogram was computed with the gap statistic (Tibshirani et al., 2001). This method compares the change in within-cluster dispersion with that expected under an appropriate reference null

distribution of the data. The rationale behind the gap statistic and the detailed procedure for its step by step computation are reported in Tibshirani et al. (2001). The clustering and related time series were represented using heat map plots of the raw dataset (Eisen et al., 1998). A heat map is a graphical representation of data where the values of a variable on a two dimensional map are represented by squares with colour gradients, and variables (here fatty acids) are ordered according to the dendrogram defined by the hierarchical clustering. Only fatty acids $>1 \mathrm{~mol} \%$ in at least one treatment combination were included in this analysis. The multivariate analysis and heat map were performed with $R$ (The $R$ foundation for statistical computing, Vienna, Austria).

\section{Results}

\subsection{Environment and seston}

Particulate organic matter (POM) in the Thau lagoon varied from $1.9 \mathrm{mg} \mathrm{L}^{-1}$ to $14.7 \mathrm{mg} \mathrm{L}^{-1}$ between 2 March 2009 and 7 April 2010, irrespective of sites and locations (Fig. 2A). The lowest POM concentrations $\left(\sim 2.7 \mathrm{mg} \mathrm{L}^{-1}\right)$ were observed from 8 June to 30 November, a period when rainfall remained fairly low and salinity in the lagoon increased markedly (Fig. 2B). In contrast, the highest POM concentrations were observed during periods of heavy rains and reduced salinity, between 2 March and 25 May 2009 and between 14 December 2009 and the end of the study period in early April 2010.

Concentrations of microphytoplankton cells $(>10 \mu \mathrm{m})$ recorded at Marseillan, within the farming area where oysters and mussels were deployed, varied as a function of sampling dates from $5.2 \times 10^{3}$ to $9.6 \times 10^{5}$ cells $\mathrm{L}^{-1}$ (Fig. $2 \mathrm{C}$ ). Phytoplankton first bloomed from 14 April to 25 May. Thereafter, cell concentrations remained fairly constant until 6 July, after which they decreased markedly until August. A second phytoplankton bloom started in mid-August and lasted until mid-September, when phytoplankton concentrations reached their peak (Fig. 2C). These two phytoplankton blooms were predominantly constituted of diatoms of the 
genus Chaetoceros sp. (see pie charts Fig. 2C). Phytoplankton concentrations decreased markedly during the autumn and winter, attaining their lowest values on 18 January.

Chlorophyll a concentrations varied from values as low as $0.3 \mu \mathrm{g} \mathrm{L}^{-1}$ up to $6.3 \mu \mathrm{g} \mathrm{L}^{-1}$, depending on date and site (Fig. 2D). Overall, three peaks of Chl a were observed, on 14 April, 22 June and 7 September 2009. Peaks in POM and Chl a did not coincide and these two variables were not correlated $\left(r^{2}=0.05, P=0.246, n=29\right.$ sampling dates $)$. However, peaks in $\mathrm{Chl}$ a coincided with the phytoplankton blooms observed in the farming area at Marseillan (Fig. 2C and 2D).

Values of $\delta^{13} \mathrm{C}$ increased markedly between 30 March to 25 May 2009, from $-24.0 \%$ o to -20.7 $\%$ and $-19.2 \%$ at Bouzigues and Marseillan, respectively (Fig. 2E). This enrichment in ${ }^{13} \mathrm{C}$ reflects the reduction of the contributions of terrestrial inputs to bulk POM, likely due to the concomitant reduction in rainfall and to the increased contribution of pelagic and benthic marine sources. Indeed, values of $\delta^{13} \mathrm{C}$ in terrestrial inputs from the rivers were lower (between $-32.3 \%$ and $-28.7 \%$ ) than those of marine POM phytoplankton (-22.8\%o), biofilms $(-21.4 \%)$ and sediment (-19.4\%, see inset in Fig. 2E). During the summer, between 8 June and 24 August, $\delta^{13} \mathrm{C}$ decreased markedly at Marseillan (from $-19.1 \%$ to $-22.4 \%$ o $\mathrm{P}<0.001$ ) and moderately at Bouzigues $(-20.7 \%$ to $-21.6 \%, P=0.111)$, reflecting the contribution of coastal marine phytoplankton to bulk POM. It is noteworthy that the three peaks in $\mathrm{Chl}$ a coincided with significant increases in $\delta^{13} \mathrm{C}$ values. Also, $\mathrm{Chl} a$ and $\delta^{13} \mathrm{C}$ values were highly correlated $\left(\mathrm{Chl} a=69.9+5.576 \times \delta^{13} \mathrm{C}+0.113 \times \delta^{13} \mathrm{C}^{2}, \mathrm{r}^{2}=0.532, \mathrm{P}<0.001, \mathrm{n}=29\right.$ sampling dates). During the autumn and the winter, $\delta^{13} \mathrm{C}$ decreased gradually until it attained its lowest values, $-26.0 \%$ at both sites on 18 January, reflecting the contributions of terrestrial inputs to bulk POM during the rainy season.

There was no effect of bivalve farming on POM, Chl a or $\delta^{13} \mathrm{C}$. Indeed, although POM and Chl a concentrations inside the farming area were respectively $4 \%$ and $19 \%$ lower than those recorded outside the farming area, the difference was not statistically significant $(P=$ 0.581 and $P=0.162$ respectively). Also, values of $\delta^{13} \mathrm{C}$ inside and outside the bivalve farming area were $-22.6 \%$ and $-22.4 \%$, respectively $(P=0.194)$.

\subsection{Growth of oysters and mussels}

Tissue dry mass of one-yr-old oysters increased by 10x from 30 March to 6 July 2009, compared with an increase of only $5 x$ in two-yr-old oysters (Fig. 3A). This period of high growth rate in oysters (Fig. 3B) was also favourable for mussels, which exhibited a $6 \times$ increase in their tissue dry mass (Fig. 3A). From 6 July to 24 August, tissue dry mass of oneand two-yr-old oysters decreased by $15 \%$ and $50 \%$, respectively, corresponding to the release of gametes. During this period, mussel tissue growth stopped. Oyster tissue mass then increased once more until mid-October and remained fairly stable thereafter (Fig. 3A). After the summer, mussel tissue dry mass increased significantly until 20 September and then decreased until early December, likely corresponding to the release of gametes. There were, therefore, two periods of high tissue growth rate in oysters and mussels (Fig. 3B). The first was from March to early July, before the spawning period, during the first diatom bloom, when $\mathrm{Chl}$ a peaked and when seawater temperature increased from $12{ }^{\circ} \mathrm{C}$ to $26{ }^{\circ} \mathrm{C}$ (mean $=$ $19.8^{\circ} \mathrm{C}$, Fig. 2B). The second high growth period was in September to October, coinciding with the second diatom bloom, when there was increased concentration in $\mathrm{Chl} a$, and seawater temperatures varied from $27^{\circ} \mathrm{C}$ to $14^{\circ} \mathrm{C}\left(\right.$ mean $\left.=21.7^{\circ} \mathrm{C}\right)$.

Overall, shell mass of oysters and mussels increased as a function of time following polynomial quadratic relationships (mass of shell $=y_{0}+a x+b x^{2}$, where $x=$ number of days since 30 March 2009, Fig. 3C). Interestingly, regressions of shell mass and time for one- and two-yr-old oysters showed similar slopes (growth rates) but different values for $y_{0}$ (initial shell mass). The rate of increase in shell mass of mussels was much lower than that of oysters. 
For both bivalve species and both age-classes, shell mass increased until it attained a plateau in mid-October (Fig. 3C). The periods of highest shell mass increment in both oysters and mussels were from March to early July and in September and October (Fig. 3D), as previously observed for soft tissues (Fig. 3B).

Although growth rates of one- and two-yr-old oysters were similar in terms of shell mass, one-yr-old animals showed a growth rate $5.3 \times$ higher than their two-yr-old counterparts in terms of shell length $\left(220 \mu \mathrm{m} \mathrm{d}^{-1}\right.$ and $41 \mu \mathrm{m} \mathrm{d}^{-1}$, respectively, between 30 March and 20 October 2009, Fig. 3E). Therefore, despite the fact that shell length of one-yr-old oysters was only $27.2 \mathrm{~mm}$ at the beginning of the study, compared with $66.6 \mathrm{~mm}$ in two-yr-old oysters, shell length of the two age-classes became similar on 20 October 2009 (mean $=73.3 \mathrm{~mm}, \mathrm{P}$ $=0.156$, Fig. 3E). It is noteworthy that shell length of one-yr-old oysters and mussels increased as a function of time following polynomial quadratic relationships, whereas shell length in two-yr-old oysters increased linearly with time. In every case, shell length attained a plateau at the end of November (Fig. 3E). The periods of highest shell length increment in one-yr-old oysters and mussels were between March and early July, as previously observed for soft tissues and shell mass (Fig. 3E and 3F). For two-yr-old oysters, it seemed that shell increment remained fairly constant over time, which clearly contrasts with the other biometrical parameters (Fig. 3F).

\section{3. $\delta^{13} \mathrm{C}$ in oysters}

Oysters showed important seasonal changes in their digestive gland isotopic composition during a one-yr cycle in the Thau lagoon (Fig. 4). Indeed, in March and April 2009, $\delta^{13} \mathrm{C}$ values were only $-21.7 \%$ and increased markedly from 12 May until reaching their peak value of $-19.4 \%$ on 8 June 2009 . This enrichment in ${ }^{13} \mathrm{C}$ likely reflects the reduction in the contribution of terrestrial inputs to the diet of oysters, due to the concomitant reduction in rainfall and the increased contribution of pelagic and benthic marine sources. $\delta^{13} \mathrm{C}$ values then decreased gradually during the summer and more markedly during the fall and the winter (Fig. 4), which is typical of an increasing contribution of terrestrial inputs into the diet of oysters. Values of $\delta^{13} \mathrm{C}$ in oysters were the lowest during spring $2010(-24.0 \%)$. It should be noted, however, that a small and almost significant increase in $\delta^{13} \mathrm{C}$ values was detected on 21 September $\left(-19.7 \%\right.$, $p_{\delta 13 C ~ 24 / 8}$ vs. $\left.21 / 9=0.072\right)$. Interestingly, there were no significant differences in $\delta^{13} \mathrm{C}$ values between one- and two-yr-old oysters (two-way ANOVA, Age: $\mathrm{P}=$ 0.593 , Date $\times$ Age: $P=0.590$ ), suggesting that both age classes fed on similar sources. Values of $\delta^{13} \mathrm{C}$ in oysters were highly correlated with those recorded in the water samples collected at Marseillan on the same sampling dates $\left(\delta^{13} \mathrm{C}_{\text {seston }}=\delta^{13} \mathrm{C}_{\text {oyster }} \times 0.928-2.68, \mathrm{r}^{2}=\right.$ $0.524, P=0.003, n=14$ sampling dates). Therefore, changes in $\delta^{13} \mathrm{C}$ values in oysters clearly reflected those occurring in POM.

\subsection{Fatty acids in oysters and mussels}

Fatty acid composition of neutral lipids in soft tissues of bivalves was represented using a heat map plot (Fig. 5). Each of the fatty acids contributing to $>1 \%$ of the total on a given sampling date is represented on the heat map for each bivalve species and age class by a square coloured according to a gradient for the whole map, and fatty acids are ordered according to a dendrogram. Four groups of fatty acids appeared distinctly (Fig. 5). The first group included the typical diatom fatty acid markers 16:1n-7, 20:4n-6 and 20:5n-3 (Budge and Parrish, 1998; Dalsgaard et al., 2003; Viso and Marty, 1993). Overall, levels of these three fatty acids increased during the spring and autumn, and levels of $16: 1 n-7$ and $20: 4 n-6$ were higher in mussels compared with oysters. This group also included 20:1n-9 and 22:5n3 , which seemed higher in mussels than in oysters, and 14:0, which showed the highest levels from 25 May until 6 July 2009 in both oysters and mussels. The second group consisted of $18: 2 n-6$ and 18:3n-3, two markers of terrestrial inputs and vascular plants (Budge and Parrish, 1998), and 18:4n-3 and 22:6n-3, which are often used as a 
dinoflagellate marker (Kharlamenko et al., 2001). Temporal changes of these fatty acids were similar among the three groups of bivalves, although the patterns in mussels differed more from those of the oyster groups than the oyster groups did from one another. The third group of fatty acids had only two members. The first, $16: 4 n-1$, is occasionally used as a diatom marker (Viso and Marty, 1993). Values for this fatty acid were generally low for the three groups of bivalves, except in spring 2010. The second, 15:0, is often associated with bacterial markers. Finally, the fourth group included a mixture of fatty acids naturally biosynthesized by bivalves, such as the saturated 16:0,17:0 and 18:0; the monounsaturated 18:1n-9 and n-7, 20:1n-11 and n-7; and the 22:2 NMI. Levels of these fatty acids seemed higher and more variable in oysters than in mussels.

The effects of bivalve species and age class and sampling date on fatty acid markers used in the scientific literature were investigated following two-way split-plot ANOVAs (Fig. 6, Table 2). The fatty acid markers investigated in this study were the ratios $16: 1 \mathrm{n}-7 / 16: 0$ and 20:5n$3 / 22: 6 n-3$, both of which indicate the contribution of diatoms to the diet of oysters and mussels (Budge and Parrish, 1998; Dalsgaard et al., 2003; Viso and Marty, 1993). Additionally, we investigated the sum of $18: 2 n-6$ and $18: 3 n-3$, which is generally considered as a marker of terrestrial inputs, and the sum of iso- and anteiso-branched chain fatty acids and unbranched 15:0 and 17:0, which reflect the contribution of bacteria to the organic matter (Budge and Parrish, 1998; Dalsgaard et al., 2003).

Species, age class and sampling date effects on 16:1n-7/16:0 interacted (Fig. 6A). Overall, this diatom marker was higher in mussels than in oysters (0.34 in oysters vs. 0.62 in mussels, $\left.p_{\mathrm{Cg} \text { vs } \mathrm{Mg}}<0.001\right)$. This reflects the fact that level of $16: 1 \mathrm{n}-7$ was $1.9 \times$ higher in mussels $(11.4 \%)$ than in oysters, where this fatty acid accounted for only $6.0 \%$ of neutral lipids. Initial values of $16: 1 \mathrm{n}-7 / 16: 0$ in mussels (0.29) were slightly higher than those in the one- and two-yr-old oysters $(\sim 0.18, \mathrm{P}=0.002$ and $\mathrm{P}=0.046$ respectively). Values of $16: 1 \mathrm{n}-$ $7 / 16: 0$ increased by $0.67,0.44$ and 0.22 in tissues of one-yr-old mussels and oysters and two-yr-old oysters, respectively, between 30 March and 18 May, during the first diatom bloom. This diatom marker became higher in one-yr-old oysters than in two-yr-old ones on 18 May $(P<0.001)$. It then decreased by $2.4 \times$ from 8 June to 24 August, and increased again until 21 September during the second diatom bloom. During the autumn and winter, values of $16: 1 n-7 / 16: 0$ decreased gradually in oysters, whereas they fluctuated in mussels.

As previously observed for $16: 1 n-7 / 16: 0$, values of $20: 5 n-3 / 22: 6 n-3$ varied according to species, age class and sampling date (Fig. 6B). Seasonal changes in this diatom marker were somewhat similar to those observed for 16:1n-7/16:0. Indeed, values of 20:5n-3/22:6n3 increased between 30 March and 18 May, during the first diatom bloom, and then decreased from 8 June to 24 August. Ratio values then increased again until 21 September, during the second diatom bloom. During the autumn and winter, values of $20: 5 n-3 / 22: 6 n-3$ decreased gradually in both oysters and mussels.

Values of $18: 2 n-6+18: 3 n-3$ were among the highest at the beginning of the study period on 30 March 2009, likely reflecting terrestrial inputs from the watershed during the rainy season. This marker of terrestrial inputs were initially higher in mussels (7.5\% of total fatty acids) than in one-yr-old oysters $(6.0 \%, \mathrm{P}=0.012)$, whereas two-yr-old oysters showed intermediate values of $6.5 \%$, not significantly different from that of mussels $(P=0.074)$ or their one-yr-old counterparts ( $P=0.449$, Fig. $6 \mathrm{C})$. Overall, this terrestrial marker decreased by $\sim 2 x$ in bivalve tissues during the spring, irrespective of species and age class, before reaching its lowest values on 8 June $(\sim 3.2 \%$, no significant difference between species and age classes, Fig. 6C). Between 8 June to 24 August, 18:2n-6+18:3n-3 increased by 1.7 to $2.6 \times$, reaching $6.5 \%$ and $7.9 \%$ of total fatty acid in two- and one-yr-old oysters respectively $(P=0.012)$. In the same period, $18: 2 n-6+18: 3 n-3$ increased in mussels by only $1.3 \times$, thus attaining lower values than those observed in oysters $(4.2 \%, P<0.001)$. During the second diatom bloom between 24 August and 21 September, terrestrial markers decreased again 
markedly in oysters to reach $\sim 4.2 \%$ of their total fatty acids, a value similar to that in mussels (3.6 \%, no significant difference with oysters). Then, this terrestrial marker increased gradually during the autumn and winter to reach $5.4 \%$ to $6.5 \%$ of the total fatty acids in early February 2010, depending on bivalve species and age class (Fig. 6C). In April 2010, values of 18:2n-6+18:3n-3 were lower than those observed during the winter for two-yr-old oysters and mussels, likely reflecting the reduction of terrestrial inputs from the watershed when rainfall decreased. It should be noted, however, that values of $18: 2 n-6+18: 3 n-3$ in one-yr-old oysters in April were similar to those recorded in February.

The sum of iso- and anteiso-branched chain fatty acids and unbranched 15:0 and 17:0 varied as a function of sampling date and bivalve species (Fig. 6D). These bacterial fatty acids were generally slightly lower in mussels than in oysters, irrespective of bivalve age (see inset in Fig. 6D); they fluctuated from $2.0 \%$ to $2.6 \%$ between 30 March and 18 May, then remained fairly low and constant at $\sim 2.2 \%$ of total fatty acids until 6 July. Then, values of this bacterial marker increased gradually during the summer to reach their highest value of $2.8 \%$ on 24 August. Finally, bacterial marker values decreased linearly from mid-October 2009 until the end of the study period on 7 April 2010, reaching a value of $2.3 \%$, similar to that observed late March 2009.

\section{Discussion}

\subsection{Seasonal changes in suspended POM}

Mean values of $\delta^{13} \mathrm{C}$ in the suspended POM (-22.5\%) in the Thau lagoon compare well to those reported in neighbouring Mediterranean lagoons: mean POM $\delta^{13} \mathrm{C}$ was $-19.7 \%$ at Salses-Leucate (Carlier et al., 2009), -22.2 \%o at Lapalme (Carlier et al., 2007) and -21.5 \%o in Lake Sabaudia, a western Mediterranean lagoon (Vizzini and Mazzola, 2003 and references therein). These values were within the range for coastal marine phytoplankton from Mediterranean surface waters: this study: -22.8\%; Dauby (1989): -22.4\%; Vizzini \& Mazzola (2003): -21.0 \%o; Darnaude et al. (2004): -22.3\%o. Overall, the most depleted and enriched values for POM $\delta^{13} \mathrm{C}$ in the Thau lagoon were observed in winter and late springearly summer respectively, which is in good agreement with other studies (Malet et al., 2008; Vizzini and Mazzola, 2003).

Seasonal variation in suspended POM $\delta^{13} \mathrm{C}$ clearly reflected hydro-climatic changes in the Thau lagoon. Indeed, $\delta^{13} \mathrm{C}$ values were as low as -24.0 to $-26.0 \%$ during rainy periods (i.e., in early spring 2009 and winter and spring 2009-10), thus suggesting that ${ }^{13} \mathrm{C}$-depleted terrestrial organic matter contributed to suspended POM, likely reflecting the effect of freshwater runoff from the catchments and rivers. Similarly, low values of $\delta^{13} \mathrm{C}(-24$ to $-23 \%)$ were reported in the POM collected in the Marennes-Oléron bay, on the French Atlantic coast, during the periods of winter and spring 2002-03 and winter 2003 (Malet et al., 2008). In this study, the POM ${ }^{13} \mathrm{C}$ depletion was attributed to the high river discharge, leading to high levels of terrigenous inputs (see also Riera and Richard, 1997).

$\delta^{13} \mathrm{C}$ increased markedly during spring 2009 , from $-24.0 \%$ to $\sim-20.0 \%$. This global enrichment in ${ }^{13} \mathrm{C}$ reflects the reduction of the contributions of ${ }^{13} \mathrm{C}$-depleted terrestrial inputs to bulk POM, likely due to the concomitant reduction in rainfall and to the increased contribution of pelagic and benthic marine sources. Phytoplankton biomass is probably a major driver of the ${ }^{13} \mathrm{C}$ signatures as $\mathrm{Chl} a$ and $\delta^{13} \mathrm{C}$ values were highly correlated. Similarly, in Lake Sabaudia, less depleted $\delta^{13} \mathrm{C}$ values were observed in summer and were attributed to the greater contribution of ${ }^{13} \mathrm{C}$-enriched organic matter within the suspended POM (Vizzini 
and Mazzola, 2003). Also, in the Bay of Brest, on the Atlantic coast of France, values of $\delta^{13} \mathrm{C}$ increased markedly during spring phytoplanktonic blooms (Lorrain et al., 2002).

During the summer of 2009 , POM $\delta^{13} \mathrm{C}$ decreased significantly at Marseillan. Although rainfall levels were at their lowest, this reduction in $\mathrm{POM} \delta^{13} \mathrm{C}$ likely reflects the signature of terrestrial inputs. This period, which was in-between two phytoplankton blooms, was characterised by a marked decrease in phytoplankton concentration and $\mathrm{Chl} a$. Therefore, the reduction in $\mathrm{POM} \delta^{13} \mathrm{C}$ would reflect a relative increase in the contribution of terrestrial inputs to the POM, due to a simultaneous reduction in the contribution of marine POM phytoplankton.

It should be noted that seasonal variations in suspended $\mathrm{POM} \delta^{13} \mathrm{C}$ in the Thau lagoon were particularly high compared with other coastal ecosystems. Indeed, POM $\delta^{13} \mathrm{C}$ varied by 5.7 and $6.8 \%$ at Bouzigues and Marseillan, respectively, compared with only $4.1 \%$ in Lake Sabaudia (Vizzini and Mazzola, 2003), and $\sim 4.0 \%$ in the Marennes-Oléron bay (Malet et al., 2008). These seasonal variations in suspended $P O M \delta^{13} \mathrm{C}$ in the semi-enclosed Thau lagoon reflect the fact that coastal lagoons are located at the frontier between land and sea, and are therefore submitted to seasonally contrasting continental and marine influences. In Mediterranean lagoons, strong seasonality in rainfall and the connection with the sea are key factors controlling the relative importance of these two influences.

\subsection{Seasonal changes in $\delta^{13} \mathrm{C}$ and fatty acids in bivalves}

The overall mean value of $\delta^{13} \mathrm{C}$ in oyster digestive gland was $-21.1 \%$, which is $1.4 \%$ higher than that of the suspended POM. This difference between oyster and POM $\delta^{13} \mathrm{C}$ is close to the well-established I \%o carbon enrichment per trophic level (DeNiro and Epstein, 1978; Fry, 2007). More particularly, the isotopic enrichment of bivalve tissues relative to suspended POM is a well-documented phenomenon (e.g. Riera and Richard, 1997). This enrichment was particularly evident in March and September 2009 and February 2010, when oyster $\delta^{13} \mathrm{C}$ differed from POM $\delta{ }^{13} \mathrm{C}$ by $\geq 2.5 \%$. These were also the periods when POM ${ }^{13} \mathrm{C}$ was the most depleted. This pattern can be partly explained by the selective ingestion of isotopicallyenriched components of the POM such as marine phytoplankton (Page and Lastra, 2003; Riera and Richard, 1997).

Results showed that seasonal changes of $\delta^{13} \mathrm{C}$ in digestive gland of oysters followed those of the suspended POM over the year, as previously reported in many studies (Kang et al., 1999; Malet et al., 2007; Marin-Leal et al., 2008; Page and Lastra, 2003; Riera and Richard, 1997). Such seasonal changes in oyster $\delta^{13} \mathrm{C}$ could be interpreted as resulting from a changing diet. Indeed, the marked increase in oyster $\delta^{13} \mathrm{C}(+2.4 \%)$, which occurred in May after the first diatom bloom, indicates assimilation of phytoplanktonic ${ }^{13} \mathrm{C}$-enriched food sources. It is generally accepted that phytoplanktonic organic matter and microphytobenthos constitute most of the bivalve diet, with variation in their relative importance depending on the location and season (Dubois et al., 2007; Kang et al., 1999; Kang et al., 2006; Lefebvre et al., 2009; Malet et al., 2007; Marin-Leal et al., 2008; Page and Lastra, 2003; Riera and Richard, 1997).

Reductions in oyster $\delta^{13} \mathrm{C}$, which occurred during summer $2009(-0.9 \%)$ and between September 2009 and March 2010 (-4.3\%), also followed those of the POM. The marked reduction in oyster $\delta^{13} \mathrm{C}$ during autumn and winter indicates assimilation of ${ }^{13} \mathrm{C}$-depleted food sources, as previously reported by Kang et al. (1999) on cockles in Marennes-Oléron Bay. Also, Riera \& Richard (1997) showed that large seasonal variations in invertebrate $\delta^{13} \mathrm{C}$ was related to high freshwater discharge into estuarine sites. They pointed out a marked decrease of $\delta^{13} \mathrm{C}$ in both the invertebrates and the ambient POM, which indicated incorporation of terrestrial organic matter during the high-flood period. In contrast, in an 
estuary where freshwater inputs are overwhelmed by seawater during high tides, terrestrial organic matter did not contribute greatly to the diets of oysters and other suspension-feeders (Dubois et al., 2007).

These seasonal changes in oyster $\delta^{13} \mathrm{C}$ are in good agreement with those occurring in fatty acid signatures. Diatom markers (ratios of $16: 1 n-7 / 16: 0$ and $20: 5 n-3 / 22: 6 n-3$ ) in soft tissues of oysters increased during the spring and early autumn of 2009 , along with diatom blooms and enriched values of $\delta{ }^{13} \mathrm{C}$ in digestive gland of oysters. Concomitantly, elevated concentrations of terrestrial fatty acids $(18: 2 n-6+18: 3 n-3)$ generally coincided with the depleted values of $\delta{ }^{13} \mathrm{C}$ that followed rainy periods (early spring 2009 and winter and spring 2009-10) or a reduction in the relative contribution of phytoplankton to food sources (summer 2009). For the first time, this study shows that both carbon isotopic and fatty acid signatures in bivalves reflect seasonal changes in food sources and environmental parameters.

In our study, bacterial fatty acids accounted for only 1.6 to $2.9 \%$ of the neutral lipids of oysters and mussels. Similarly, these fatty acids represented $\sim 3.1 \%$ of the neutral lipids in 3yr-old oysters sampled during the reproductive period (Soudant et al., 1999). Bacteria likely represent a minor food source for bivalves in the Thau lagoon, as previously reported in oysters (Dupuy et al., 2000a) and in several mussel species (Kreeger and Newell, 1996; 2001; Safi and Hayden, 2010; Trottet et al., 2008b). Marine bacteria are predominantly less than I $\mu \mathrm{m}$ in diameter, a size that is too small to be efficiently retained on the gills of most bivalves (e.g. Riisgard, 1988). Consequently, free-living bacteria meet only about $10 \%$ of the nutritional requirements of suspension-feeding bivalves (Langdon and Newell, 1990), although they may represent a significant source of food when they are clustered or attached to particles (Kach and Ward, 2008).

The contribution of bacterial fatty acids to the neutral lipids of oysters and mussels increased suddenly on 27 April at the same time as sudden and massive mortality of oyster spat occurred in the Thau lagoon (Pernet et al., 2010b). This increase in bacterial fatty acids probably reflects an increase in the decomposition processes of surrounding dead animals or the proliferation of pathogenic or opportunistic bacteria associated with the epizooty. Similarly, Pernet et al. (2010a) showed that an increase in the contribution of bacterial fatty acid to the neutral lipids of oysters coincided with a mortality event in the Thau lagoon.

Values of the bacterial marker increased gradually in bivalve tissues during the summer and remained high during the autumn. This agrees well with the fact that bacterial production, estimated from incorporation of $\left[{ }^{3} \mathrm{H}\right]$ thymidine into DNA, is the highest in summer and autumn throughout the Thau lagoon (Troussellier et al., 1993). Likewise, in a saltmarsh ecosystem, bacterial concentrations in summer were $2 \times$ higher than in November and March (Huang et al., 2003). In our study, the increase in bacterial fatty acids in bivalve tissues during the summer and autumn probably reflects an enhancement of the microbial loop or decomposition processes in the Thau lagoon.

\subsection{Trophic relationship between oysters and mussels}

Interestingly, oysters and mussels showed similar seasonal patterns in their fatty acid signatures, thus suggesting that these two bivalve species used similar food sources. However, levels of several fatty acids differed between the two bivalve species. Level of 16:1n-7 was consistently higher in mussels than in oysters. Also, the level of 20:5n-3, another diatom fatty acid, was higher in mussel than in oyster during the summer. During the same season, level of terrestrial fatty acids increased markedly in oysters and only moderately in mussels. Finally, bacterial fatty acids in oysters were slightly, but consistently, higher than in mussels. Based on these results, it is likely that mussels relied more on diatoms and less on terrestrial organic matter and bacteria than oysters did, particularly 
during the summer when phytoplankton biomass was low. In support of this hypothesis, Riera et al. (2002) reported differences in carbon and nitrogen isotope ratios between $C$. gigas and other suspension feeding molluscs, including the mussel Mytilus edulis. It is therefore likely that, when organic matter consists of mixed sources, inter-specific differences in particle sorting strategy reduce competition among bivalve species, as previously reported in suspension-feeders (Lefebvre et al., 2009).

However, it is important to point out that differences in neutral lipid fatty acids do not only mirror differences in food sources. They also reflect selective incorporation and utilization processes of fatty acids, which depend on species-specific physiological requirement. For example, a previous study revealed that two bivalve species fed the same diet in a controlled environment can exhibit major differences in their neutral lipid fatty acids (Pernet et al., 2007). These authors showed that mussels ( $M$. edulis) were better able to selectively incorporate $20: 5 n-3$ in their neutral lipids than oysters (C. virginica) did during overwintering. Also, scallop larvae fed a diet rich in $20: 5 n-3$ preferentially accumulated $22: 6 n-3$ in their neutral lipids at the expense of 20:5n-3 (Delaunay et al., 1993). Therefore, the use of fatty acids as trophic markers requires caution as they also reflect physiological requirements of animals.

\subsection{Between-age variation in $\delta^{13} \mathrm{C}$ and fatty acids in oysters}

One- and two-yr-old oysters showed similar values of $\delta^{13} \mathrm{C}$. The lack of age effect on values of $\delta^{13} \mathrm{C}$ likely reflects the fact that these two groups of oysters fed on similar sources of organic matter, despite the fact that their metabolic rates and reproductive effort were markedly different (Pernet et al., 2010b). In contrast, carbon isotopes reveal that adult cockles rely on suspended POM while spat and juveniles are more closely linked to microphytobenthos (Kang et al., 1999). The isotopic shifts indicate that the relative importance of the two major food sources depends on the age of the cockles. Also, values of $\delta^{13} \mathrm{C}$ depended significantly on body size in $M$. balthica, providing evidence of ontogenetic variation in diet, with small juveniles feeding entirely on microphytobenthos but a gradual tendency for larger sizes to feed more on microphytoplankton (Rossi et al., 2004). In our study, similarities in values of $\delta^{13} \mathrm{C}$ in one- and two-yr-old oysters may reflect the fact the two groups of oysters have the same feeding mode. Also, there was no ontogenic shift in diet between one- and two-yr-old oysters. Indeed, gills were fully developed in both groups of oysters as shell length was higher than $7.5 \mathrm{~mm}$ (Cannuel and Beninger, 2006). Therefore, filtration capacity, sorting strategy and food ingestion were similar in one- and two-yr-old oysters.

However, one- and two-yr-old oysters showed small but significant differences in their neutral lipid fatty acids. During spring phytoplankton blooms, the ratio of $16: 1 n-7 / 16: 0$ and 20:5n$3 / 22: 6 n-3$ in one-yr-old oysters were higher than that of two-yr-old animals. Also, during the summer, when the contribution of terrestrial inputs to the POM increased slightly due to the concomitant reduction of phytoplankton biomass, the level of terrestrial fatty acids (18:2n$6+18: 3 n-3)$ increased more markedly in one-yr-old oysters than in two-yr-olds. Therefore, it seems that one-yr-old oysters imprinted their trophic environment more strongly than two-yrolds. This likely reflects the fact that metabolic rates, including clearance rate, vary in an allometric manner with size, such that small animals filter proportionally more than large ones (e.g. Bougrier et al., 1995). At the end of the experiment, when one- and two-yr-old oysters were of the same size, values of these fatty acid markers became similar or varied inconsistently with size. 


\subsection{Growth rate of bivalves and seasonal changes in food sources}

Seasonal variations in growth parameters of bivalves in our study are in good agreement with previously published data on oysters (Gangnery et al., 2003) and mussels (Gangnery et al., 2004) in the Thau lagoon. Dynamics of oyster growth in the Thau lagoon were also very similar to those reported in a coastal pond in Marennes-Oléron by Bourlès et al. (2009). Briefly, during the winter, no growth was observed due to the low phytoplankton biomass and temperature that was generally below $8{ }^{\circ} \mathrm{C}$. From March to June, high growth rate was sustained by several blooms of diatoms and by increasing temperatures from $12{ }^{\circ} \mathrm{C}$ to $26{ }^{\circ} \mathrm{C}$. Summer seawater temperatures higher than $25^{\circ} \mathrm{C}$ in July affected the dynamics of oyster food uptake. This temperature peak, in addition to the spawning event, explained the marked decrease of tissue dry mass in July. In August, low levels of phytoplankton and elevated temperature induced no tissue growth. In September and October, another phytoplankton bloom and decreasing temperature (from $27^{\circ} \mathrm{C}$ to $14^{\circ} \mathrm{C}$ ) remained optimal to sustain growth of oysters.

The two periods of high tissue growth rate in both oysters and mussels coincided with spring and autumn diatom blooms. Stable isotope and lipid analyses of soft tissues confirm that these bivalves do benefit from the diatom blooms. Values of $\delta^{13} \mathrm{C}$ in soft tissues of oysters increased during these diatom blooms, reflecting the increased contribution of pelagic and benthic marine sources. Fatty acid diatom markers in oysters and mussels also peaked during diatom blooms. Therefore, high tissue growth rate in both oysters and mussels in the Thau lagoon is mainly fuelled by diatoms. This result supports Dupuy et al. (2000b), which showed, over a short-term experiment, that diatoms were the main food source for oysters in Thau lagoon. Similarly, tissue growth and gonadal development of two intertidal bivalves occurred together during late spring and summer when diatom concentrations were the highest (Kang et al., 2006). In other coastal ecosystems, phytoplankton was the predominant food source for oysters (Marin-Leal et al., 2008). These results highlight the importance of seasonal development of microphytoplankton as an available food source during the critical period of growth and gamete production in bivalves. A recent modelling study shows that phytoplankton enumeration works well as a food quantifier, reproducing the growth and reproduction of $C$. gigas very accurately (Bourlès et al., 2009).

\subsection{Impact of bivalve farming}

Chlorophyll a concentrations inside the farming area were only $19 \%$ lower than those recorded outside, which was not significantly different. In contrast, some studies have found a large impact of shellfish farms on plankton communities and particularly on $\mathrm{Chl} \mathrm{a}$ concentrations. For example, a study conducted in 1991-92 reported that the presence of shellfish farms led to a $\sim 40 \%$ deficit in $\mathrm{Chl} a$ in the western part of the Thau lagoon (Souchu et al., 2001). These authors also mentioned that $\mathrm{Chl}$ a concentrations remained near or below $0.9 \mathrm{\mu g} \mathrm{L}^{-1}$, which is $2 \times$ lower than those reported here, as average $\mathrm{Chl}$ a concentration within the shellfish farm at Bouzigues was $1.8 \mu \mathrm{g} \mathrm{L}^{-1}$. It is probable that bivalve grazing pressure within the farming area has decreased since the report of Souchu et al. (2001), so that concentrations of $\mathrm{Chl}$ a have increased and differences between farmed and wild area has been attenuated. In support of this hypothesis, an extensive survey of farming practices conducted during the spring 2011 in the Thau lagoon revealed that $20 \%$ of the farm concessions are empty (not exploited) and only $25 \%$ are fully exploited, a reduction in activity that is due to the mass mortality of young oysters that has impacted the Thau lagoon for the last 4 years $(n=458$ concessions sampled, representing $\sim 18 \%$ of the total number of concessions in the Thau lagoon, Pernet et al. unpublished data). Therefore, our work agrees well with Trottet et al. (2008a), who reported that suspended mussel farming in a Canadian lagoon has no impact on the water column. These authors found similar planktonic species 
inside and outside of a mussel farm area in summer and also observed that heterotrophic species and phytoplankton $<20 \mu \mathrm{m}$ made up the bulk of the available plankton at both stations.

Although differences in POM $\delta^{13} \mathrm{C}$ recorded inside and outside of the shellfish farming area were not significant, they were consistent with the Chl a concentrations. Values of POM $\delta^{13} \mathrm{C}$ were slightly higher outside the shellfish farming area (-22.6\%o vs. $-22.4 \%$ ) where Chl $a$ concentrations were also slightly higher than inside. It is therefore likely that reduced $\mathrm{Chl} a$ concentrations due bivalve grazing on microphytoplankton in shellfish farming areas would lead to decreasing values of POM $\delta^{13} \mathrm{C}$ due to the decreasing contribution of ${ }^{13} \mathrm{C}$-enriched marine phytoplankton to bulk POM. Although there was no significant effect of shellfish farms on Chl a concentration and POM $\delta^{13} \mathrm{C}$ in our study, it nonetheless seems that stable isotopes could be successfully used to investigate the effects of bivalve aquaculture on the environment, as previously reported for finfish (e.g. Sara et al., 2006; Yokoyama et al., 2006).

\section{Conclusion}

This study shows that both carbon isotope and fatty acid signatures in bivalves growing in the Thau Mediterranean lagoon reflect seasonal changes in food sources, which vary according to environmental parameters. Overall, marked seasonal changes in $\delta^{13} \mathrm{C}$ and fatty acids in oysters and mussels suggest that dietary phytoplankton contribution varied seasonally. Other food sources, such as terrestrial inputs and bacteria, can contribute during non-bloom periods, emphasizing the trophic plasticity of bivalves. Mussels seem to rely more on diatoms and less on terrestrial organic matter and bacteria than do oysters, which may reduce interspecific competition when phytoplankton biomass is low during the summer. Although one- and two-yr-old oysters showed similar values of $\delta^{13} \mathrm{C}$, their fatty acid dynamics differed subtly, in good agreement with their physiology. Therefore, fatty acid analyses do not only allow the interpretation of stable isotopic results to be confirmed, as these represent complementary tools for the investigation of trophic ecology in aquatic ecosystems. Furthermore, fatty acid analyses allow the possible role of bacteria in the trophic ecology of aquatic ecosystems to be investigated; this aspect has previously often been ignored in stable isotope studies, probably due to the technical difficulties of separating sufficient bacterial biomass from other types of particles in order to characterize their isotopic signature (Huang et al., 2003). When used together, stable isotopes and fatty acids are a promising approach to understanding the trophic ecology of complex aquatic ecosystems.

\section{Acknowledgements}

The authors are grateful to Patrik Le Gall and Jean Barret of the Ifremer Laboratoire Environnement Ressources en Languedoc-Roussillon for their help with fieldwork. The authors also wish to thank Pierre Besrest, Solenn Soriano, Eve-Julie Arsenault-Pernet, Marine Miguet, Lucette Joassard, Elise Hattey, and Anaïs Crottier for their careful lab work. The authors also wish to thank the staff involved in environmental and shellfish networks (REPHY and Observatoire Conchylicole). Finally, the authors express their gratitude to Helen McCombie for revising the English version of this manuscript. This work was supported by grants from Région Languedoc-Roussillon, Conseil Général de l'Hérault and Fond Européen pour la Pêche to the Ifremer ADECOM project. 


\section{References}

Allan, E.L., Ambrose, S.T., Richoux, N.B., Froneman, P.W., 2010. Determining spatial changes in the diet of nearshore suspension-feeders along the South African coastline: Stable isotope and fatty acid signatures. Estuar. Coast. Shelf Sci. 87, 463471.

Bougrier, S., Geairon, P., Deslouspaoli, J.M., Bacher, C., Jonquieres, G., 1995. Allometric relationships and effects of temperature on clearance and oxygen-consumption rates of Crassostrea gigas (Thunberg). Aquaculture 134, 143-154.

Bourlès, Y., Alunno-Bruscia, M., Pouvreau, S., Tollu, G., Leguay, D., Arnaud, C., Goulletquer, P., Kooijman, S.A.L.M., 2009. Modelling growth and reproduction of the Pacific oyster Crassostrea gigas: Advances in the oyster-DEB model through application to a coastal pond. J. Sea Res. 62, 62-71.

Budge, S.M., Parrish, C.C., 1998. Lipid biogeochemistry of plankton, settling matter and sediments in Trinity Bay, Newfoundland. II. Fatty acids. Organic Geochem. 29, 15471559.

Cannuel, R., Beninger, P.G., 2006. Gill development, functional and evolutionary implications in the Pacific oyster Crassostrea gigas (Bivalvia : Ostreidae). Mar. Biol. 149, 547-563.

Carlier, A., Riera, P., Amouroux, J.-M., Bodiou, J.-Y., Desmalades, M., Grémare, A., 2009. Spatial heterogeneity in the food web of a heavily modified Mediterranean coastal lagoon: stable isotope evidence. Aquatic Biol. 5, 167-179.

Carlier, A., Riera, P., Amouroux, J.-M., Bodiou, J.-Y., Escoubeyrou, K., Desmalades, M., Caparros, J., Grémare, A., 2007. A seasonal survey of the food web in the Lapalme Lagoon (northwestern Mediterranean) assessed by carbon and nitrogen stable isotope analysis. Estuar. Coast. Shelf Sci. 73, 299-315.

Cloern, J.E., Canuel, E.A., Harris, D., 2002. Stable carbon and nitrogen isotope composition of aquatic and terrestrial plants of the San Francisco Bay estuarine system. Limnol. Oceanogr. 47, 713-729.

Dalsgaard, J., St. John, M., Kattner, G., Muller-Navarra, D., Hagen, W., 2003. Fatty acid trophic markers in the pelagic marine environment. Adv. Mar. Biol. 46, 225-340.

Dame, R., Prins, T., 1997. Bivalve carrying capacity in coastal ecosystems. Aquatic Ecology 31, 409-421.

Dang, C., Sauriau, P.G., Savoye, N., Caill-Milly, N., Martinez, P., Millaret, C., Haure, J., de Montaudouin, X., 2009. Determination of diet in Manila clams by spatial analysis of stable isotopes. Mar. Ecol. Prog. Ser. 387, 167-177.

Darnaude, A.M., Salen-Picard, C., Polunin, N.V.C., Harmelin-Vivien, M.L., 2004. Trophodynamic linkage between river runoff and coastal fishery yield elucidated by stable isotope data in the Gulf of Lions (NW Mediterranean). Oecologia 138, 325-332.

Dauby, P., 1989. The stable carbon isotope ratios in benthic food webs of the gulf of Calvi, Corsica. Continental Shelf Research 9, 181-195.

Delaunay, F., Marty, Y., Moal, J., Samain, J.-F., 1993. The effect of monospecific algal diets on growth and fatty acid composition of Pecten maximus (L.) larvae. J. Exp. Mar. Biol. Ecol. 173, 163-179.

DeNiro, M.J., Epstein, S., 1978. Influence of diet on the distribution of carbon isotopes in animals. Geochimica et Cosmochimica Acta 42, 495-506. 
Dubois, S., Orvain, F., Marin-Leal, J.C., Ropert, M., Lefebvre, S., 2007. Small-scale spatial variability of food partitioning between cultivated oysters and associated suspensionfeeding species, as revealed by stable isotopes. Mar. Ecol. Prog. Ser. 336, 151-160.

Dupuy, C., Pastoureaud, A., Ryckaert, M., Sauriau, P.G., Montanie, H., 2000a. Impact of the oyster Crassostrea gigas on a microbial community in Atlantic coastal ponds near La Rochelle. Aquat Microbial Ecol 22, 227-242.

Dupuy, C., Vaquer, A., Lam-Hoai, T., Rougier, C., Mazouni, N., Lautier, J., Collos, Y., Le Gall, S., 2000b. Feeding rate of the oyster Crassostrea gigas in a natural planktonic community of the Mediterranean Thau Lagoon. Mar. Ecol. Prog. Ser. 205, 171-184.

Eisen, M.B., Spellman, P.T., Brown, P.O., Botstein, D., 1998. Cluster analysis and display of genome-wide expression patterns. Proceedings of the National Academy of Sciences of the United States of America 95, 14863-14868.

Folch, J., Lees, M., Sloane-Stanlez, G.H., 1957. A simple method for the isolation and purification of total lipids from animal tissues. J. Biol. Chem. 226, 497-509.

Fry, B., 2007. Stable Isotpope Ecology. Springer Science, New York.

Galois, R., Richard, P., Fricourt, B., 1996. Seasonal Variations in Suspended Particulate Matter in the Marennes-Oléron Bay, France, using Lipids as Biomarkers. Estuar. Coast. Shelf Sci. 43, 335-357.

Gangnery, A., Bacher, C., Buestel, D., 2004. Application of a population dynamics model to the Mediterranean mussel, Mytilus galloprovincialis, reared in Thau Lagoon (France). Aquaculture 229, 289-313.

Gangnery, A., Chabirand, J.M., Lagarde, F., Le Gall, P., Oheix, J., Bacher, C., Buestel, D., 2003. Growth model of the Pacific oyster, Crassostrea gigas, cultured in Thau Lagoon (Mediterranee, France). Aquaculture 215, 267-290.

Herman, P.M.J., Middelburg, J.J., Widdows, J., Lucas, C.H., Heip, C.H.R., 2000. Stable isotopes' as trophic tracers: combining field sampling and manipulative labelling of food resources for macrobenthos. Mar. Ecol. Prog. Ser. 204, 79-92.

Huang, S.C., Kreeger, D.A., Newell, R.I.E., 2003. Seston available as a food resource for the ribbed mussel (Geukensia demissa) in a North American, mid-Atlantic saltmarsh. Estuar. Coast. Shelf Sci. 56, 561-571.

Kach, D.J., Ward, J.E., 2008. The role of marine aggregates in the ingestion of picoplanktonsize particles by suspension-feeding molluscs. Mar. Biol. 153, 797-805.

Kang, C.K., Sauriau, P.G., Richard, P., Blanchard, G.F., 1999. Food sources of the infaunal suspension-feeding bivalve Cerastoderma edule in a muddy sandflat of MarennesOleron Bay, as determined by analyses of carbon and nitrogen stable isotopes. Mar. Ecol. Prog. Ser. 187, 147-158.

Kang, C.K., Lee, Y.W., Choy, E.J., Shin, J.K., Seo, I.S., Hong, J.S., 2006. Microphytobenthos seasonality determines growth and reproduction in intertidal bivalves. Mar. Ecol. Prog. Ser. 315, 113-127.

Kharlamenko, V.I., Kiyashko, S.I., Imbs, A.B., Vyshkvartzev, D.I., 2001. Identification of food sources of invertebrates from the seagrass Zostera marina community using carbon and sulfur stable isotope ratio and fatty acid analyses. Mar. Ecol. Prog. Ser. 220, 103117.

Kreeger, D.A., Newell, R.I.E., 1996. Ingestion and assimilation of carbon from cellulolytic bacteria and heterotrophic flagellates by the mussels Geukensia demissa and Mytilus edulis (Bivalvia, Mollusca). Aquat Microbial Ecol 11, 205-214. 
Kreeger, D.A., Newell, R.I.E., 2001. Seasonal utilization of different seston carbon sources by the ribbed mussel, Geukensia demissa (Dillwyn) in a mid-Atlantic salt marsh. J. Exp. Mar. Biol. Ecol. 260, 71-91.

Langdon, C.J., Newell, R.I.E., 1990. Utilization of detritus and bacteria as food sources by 2 bivalve suspension-feeders, the Oyster Crassostrea virginica and the Mussel Geukensia demissa. Mar. Ecol. Prog. Ser. 58, 299-310.

Lebreton, B., Richard, P., Galois, R., Radenac, G., Pfleger, C., Guillou, G., Mornet, F., Blanchard, G.F., 2011. Trophic importance of diatoms in an intertidal Zostera noltii seagrass bed: Evidence from stable isotope and fatty acid analyses. Estuar. Coast. Shelf Sci. 92, 140-153.

Lefebvre, S., Marín Leal, J.C., Dubois, S., Orvain, F., Blin, J.-L., Bataillé, M.-P., Ourry, A., Galois, R., 2009. Seasonal dynamics of trophic relationships among co-occurring suspension-feeders in two shellfish culture dominated ecosystems. Estuar. Coast. Shelf Sci. 82, 415-425.

Lorrain, A., Paulet, Y.M., Chauvaud, L., Savoye, N., Donval, A., Saout, C., 2002. Differential delta $\mathrm{C}-13$ and delta $\mathrm{N}-15$ signatures among scallop tissues: implications for ecology and physiology. J. Exp. Mar. Biol. Ecol. 275, 47-61.

Malet, N., Sauriau, P.G., Faury, N., Soletchnik, P., Guillou, G., 2007. Effect of seasonal variation in trophic conditions and the gametogenic cycle on delta $\mathrm{C}-13$ and delta $\mathrm{N}$ 15 levels of diploid and triploid Pacific oysters Crassostrea gigas. Mar. Ecol. Prog. Ser. 346, 203-217.

Malet, N., Sauriau, P.G., Ryckaert, M., Malestroit, P., Guiljou, G., 2008. Dynamics and sources of suspended particulate organic matter in the Marennes-Oleron oyster farming bay: Insights from stable isotopes and microalgae ecology. Estuar. Coast. Shelf Sci. 78, 576-586.

Marin-Leal, J.C., Dubois, S., Orvain, F., Galois, R., Blin, J.L., Ropert, M., Bataille, M.P., Ourry, A., Lefebvre, S., 2008. Stable isotopes (delta C-13, delta N-15) and modelling as tools to estimate the trophic ecology of cultivated oysters in two contrasting environments. Mar. Biol. 153, 673-688.

Marty, Y., Delaunay, F., Moal, J., Samain, J.-F., 1992. Changes in the fatty acid composition of Pecten maximus (L.) during larval development. J. Exp. Mar. Biol. Ecol. 163, 221234.

Metcalfe, L.D., Schmitz, A.A., 1961. The rapid preparation of fatty acid esters for gas chromatographic analysis. Anal. Chem. 33, 363-364.

Neveux, J., Lantoine, F., 1993. Spectrofluorimetric assay of chlorophylls and phaeopigments using the least squares approximation technique. Deep Sea Res. 40, 1747-1765.

Page, H.M., Lastra, M., 2003. Diet of intertidal bivalves in the Ria de Arosa (NW Spain): evidence from stable $\mathrm{C}$ and $\mathrm{N}$ isotope analysis. Mar. Biol. 143, 519-532.

Pernet, F., Tremblay, R., Comeau, L., Guderley, H., 2007. Temperature adaptation in two bivalve species from different thermal habitats: energetics and remodelling of membrane lipids. J. Exp. Biol. 210, 2999-3014.

Pernet, F., Barret, J., Marty, C., Moal, J., Le Gall, P., Boudry, P., 2010a. Environmental anomalies, energetic reserves and fatty acid modifications in oysters coincide with an exceptional mortality event. Mar. Ecol. Prog. Ser. 401, 129-146.

Pernet, F., Barret, J., Gall, P.L., Malet, N., Pastoureaud, A., Munaron, D., Lorgeril, J.D., Bachère, E., Vaquer, A., Huvet, A., Corporeau, C., Normand, J., Boudry, P., Moal, J., Quéré, C., Quillien, V., Daniel, J.Y., Pépin, J.-F., Saulnier, D., Gonzalez, J.L., 
Bouchoucha, M., 2010b. Mortalité du naissain d'Huître creuse Crassostrea gigas dans l'étang de Thau en 2009. Ifremer, pp. 86.

Riera, P., Richard, P., 1997. Temporal variation of $\delta^{13} \mathrm{C}$ in particulate organic matter and oyster Crassostrea gigas in Marennes-Oleron Bay (France): effect of freshwater inflow. Mar. Ecol. Prog. Ser. 147, 105-115.

Riera, P., Stal, L.J., Nieuwenhuize, J., 2002. delta C-13 versus delta N-15 of co-occurring molluscs within a community dominated by Crassostrea gigas and Crepidula fornicata (Oosterschelde, The Netherlands). Mar. Ecol. Prog. Ser. 240, 291-295.

Riisgard, H.U., 1988. Efficiency of particle retention and filtration rate in 6 species of Northeast american bivalves. Mar. Ecol. Prog. Ser. 45, 217-223.

Rossi, F., Herman, P.M.J., Middelburg, J.J., 2004. Interspecific and intraspecific variation of delta $\mathrm{C}-13$ and delta $\mathrm{N}-15$ in deposit- and suspension-feeding bivalves (Macoma balthica and Cerastoderma edule): Evidence of ontogenetic changes in feeding mode of Macoma balthica. Limnol. Oceanogr. 49, 408-414.

Safi, K.A., Hayden, B., 2010. Differential grazing on natural planktonic populations by the mussel Perna canaliculus. Aquatic Biol. 11, 113-125.

Sara, G., Scilipoti, D., Milazzo, M., Modica, A., 2006. Use of stable isotopes to investigate dispersal of waste from fish farms as a function of hydrodynamics. Mar. Ecol. Prog. Ser. 313, 261-270.

Souchu, P., Vaquer, A., Collos, Y., Landrein, S., Deslous-Paoli, J.M., Bibent, B., 2001. Influence of shellfish farming activities on the biogeochemical composition of the water column in Thau lagoon. Mar. Ecol. Prog. Ser. 218, 141-152.

Soudant, P., Van, R.K., Marty, Y., Moal, J., Samain, J.F., Sorgeloos, P., 1999. Comparison of the lipid class and fatty acid composition between a reproductive cycle in nature and a standard hatchery conditioning of the Pacific oyster Crassostrea gigas. Comp. Biochem. Physiol. B. Biochem. Mol. Biol. 123, 209-222.

Tibshirani, R., Walther, G., Hastie, T., 2001. Estimating the number of clusters in a data set via the gap statistic. Journal of the Royal Statistical Society: Series B (Statistical Methodology) 63, 411-423.

Trottet, A., Roy, S., Tamigneaux, E., Lovejoy, C., Tremblay, R., 2008a. Influence of suspended mussel farming on planktonic communities in Grande-Entree Lagoon, Magdalen Islands (Quebec, Canada). Aquaculture 276, 91-102.

Trottet, A., Roy, S., Tamigneaux, E., Lovejoy, C., Tremblay, R., 2008b. Impact of suspended mussels (Mytilus edulis L.) on plankton communities in a Magdalen Islands lagoon (Quebec, Canada): A mesocosm approach. J. Exp. Mar. Biol. Ecol. 365, 103-115.

Troussellier, M., Cahet, G., Lebaron, P., Baleux, B., 1993. Distribution and Dynamics of Bacterial Production in Relation to Wind Perturbations in a Mediterranean Lagoon. Limnol. Oceanogr. 38, 193-201.

Viso, A.-C., Marty, J.-C., 1993. Fatty acids from 28 marine microalgae. Phytochemistry 34, 1521-1533.

Vizzini, S., Mazzola, A., 2003. Seasonal variations in the stable carbon and nitrogen isotope ratios $(\mathrm{C}-13 / \mathrm{C}-12$ and $\mathrm{N}-15 / \mathrm{N}-14)$ of primary producers and consumers in a western Mediterranean coastal lagoon. Mar. Biol. 142, 1009-1018.

Ward, J., 1963. Hierarchical grouping to optimize an objective function. Journal of American Statistical Association 58, 236-244. 
Yokoyama, H., Abo, K., Ishihi, Y., 2006. Quantifying aquaculture-derived organic matter in the sediment in and around a coastal fish farm using stable carbon and nitrogen isotope ratios. Aquaculture 254, 411-425.

\section{Tables}

Table 1. Seston analyses. Design of the factorial three-way repeated measure ANOVA on the effect of site (Marseillan vs. Bouzigues), location (inside vs. outside of the bivalve farming area) and sampling date (29 dates between 2 March 2009 and 7 April 2010) on seston analyses of the Thau lagoon.

\begin{tabular}{ll}
\hline Sources of variation & $\mathrm{df}$ \\
\hline Between-subject analysis & \\
$\quad$ Site & 1 \\
Location & 1 \\
Error A: Site $\times$ Location & 1 \\
& \\
Within-subject analysis & \\
Date & 28 \\
Date $\times$ Site & 28 \\
Date $\times$ Location & 28 \\
Error B: Date $\times$ Site $\times$ Location & 28
\end{tabular}

*Variables were particulate organic matter $\left(\mathrm{mg} \mathrm{L}^{-1}\right)$, chlorophyll $a\left(\mu \mathrm{g} \mathrm{L}^{-1}\right)$ and $\delta^{13} \mathrm{C}(\%)$ and fatty acids (mol \%). 
Table 2. Design of the factorial two-way repeated measure ANOVA on the effect of species Crassostrea gigas and Mytilus galloprovincialis, age class (oysters: one- and two-year-old, mussels: one-yr-old only) and sampling date (between 30 March 2009 and 7 April 2010) on biometrical parameters, stable isotope and fatty acid composition of soft tissues.

\begin{tabular}{|c|c|c|c|}
\hline \multirow[t]{2}{*}{ Sources of variation } & \multicolumn{3}{|c|}{ Df } \\
\hline & Biometry $^{*}$ & Fatty acid† & Isotopef \\
\hline \multicolumn{4}{|l|}{ Between-subject analysis } \\
\hline Species and age & 2 & 2 & \\
\hline Cg-1 vs. Cg-2 & & 1 & 1 \\
\hline $\mathrm{Cg}(-1$ and -2$)$ vs. $\mathrm{Mg}$ & & 1 & \\
\hline Error $\mathrm{A}_{1}$ : Sp. and age (replicate) & $11-12$ & 6 & \\
\hline Error $\mathrm{A}_{2}$ : Age (replicate) & & & 4 \\
\hline \multicolumn{4}{|l|}{ Within-subject analysis } \\
\hline Date & 14 & 13 & 14 \\
\hline Date $\times$ Sp. and age & 28 & 26 & \\
\hline Date $\times$ Age & & & 14 \\
\hline Error $\mathrm{B}_{1}$ : Date $\times$ Sp. and age (replicate) & $102-124$ & 76 & \\
\hline Error $\mathrm{B}_{2}$ : Date $\times$ Age (replicate) & & & 56 \\
\hline \multicolumn{4}{|c|}{$\begin{array}{l}\text { Biometry consisted of flesh and shell dry mass and shell length of oysters and mussels ( } n= \\
3 \text { for one-yr-old animals and } n=6 \text { for two-yr-old oysters) } \\
\text { † Fatty acid analyses of neutral lipids were conducted on oysters and mussels }(n=3) \text {. } \\
\text { † Isotopic analyses were conducted on oysters only }(n=3) \text {. }\end{array}$} \\
\hline
\end{tabular}

\section{Figures}

Figure 1. Map of the Thau lagoon showing the sampling sites. Seston was collected at the four sites (white circles). Oysters and mussels were deployed and sampled at Marseillan within the farming area (dotted circle). The chequered areas indicate bivalve farming areas.

Figure 2. Temporal variations in (A) particulate organic matter (black line) and monthly rainfall (grey columns), (B) temperature and salinity, (C) concentration of phytoplankton, (D) concentration of chlorophyll $a$, and $(E) \delta^{13} \mathrm{C}$ in the seston collected in the Thau lagoon from March 2009 to April 2010. (C) Pie charts = relative abundance of each taxonomic group or species of phytoplankton based on 2009-10 monthly means. The inset in part E shows values of $\delta^{13} \mathrm{C}$ in selected sources of organic matter. Data from different sites (Bouzigues and Marseillan) and locations (inside and outside of the farming area) were pooled together when no significant effect was detected. Concentrations of phytoplankton (C) were evaluated only at Marseillan, inside the farming area (source REPHY, Ifremer). Data are presented with a single error bar provided by the model standard error $( \pm S E)$. 
Figure 3. Temporal variations in (A, B) tissue dry mass, $(C, D)$ shell mass and $(E, F)$ shell length of one- and two-yr-old oysters and one-yr-old mussels (Cg-1, Cg-2 and $\mathrm{Mg}-1$, respectively) maintained in the Thau lagoon from March 2009 to April 2010. The graphs on the left side show absolute values while those on the right side display growth rate based on differences between two sampling dates. Data are presented with a single error bar provided by the model standard error ( \pm SE).

Figure 4. Temporal variations of $\delta^{13} \mathrm{C}$ in one- and two-yr-old oysters Crassostrea gigas maintained within the farming area of the Thau lagoon at Marseillan, from March 2009 to April 2010. Data from different age classes were pooled together since no significant effect was detected. Data are presented with a single error bar provided by the model standard error $( \pm \mathrm{SE})$.

Figure 5. Heat map plots showing time series of fatty acids contributing to $>1 \mathrm{~mol} \%$ of total fatty acids averaged by sampling dates in the three groups of bivalves (one- and two-yr-old oysters Crassostrea gigas and one-yr-old mussels Mytilus galloprovincialis, Cg-1, Cg-2 and $\mathrm{Mg}-1$, respectively). Fatty acids were reordered according to the hierarchical clustering result given by the dendrogram. The horizontal white lines separate the 4 groups of fatty acid identified by the gap statistic applied to the dendrogram.

Figure 6. Temporal variations in fatty acid food web markers in one- and two-yr-old oysters Crassostrea gigas and one-yr-old mussels Mytilus galloprovincialis ( $\mathrm{Cg}-1, \mathrm{Cg}-2$ and $\mathrm{Mg}-1$, respectively) maintained in the Thau lagoon from March 2009 to April 2010. Food web markers are (A) 16:1n-7/16:0 and (B) 20:5n-3/22:6n-3, which both indicate the relative importance of diatoms; (C) 18:2n-6+18:3n-3, which indicates the contribution of terrestrial inputs; and (D) 15:0+17:0+branched fatty acids, which shows the contribution of bacteria to the organic matter. Data from different age classes and species were pooled together when no significant effect was detected. Data are presented with a single error bar provided by the model standard error $( \pm \mathrm{SE})$. 


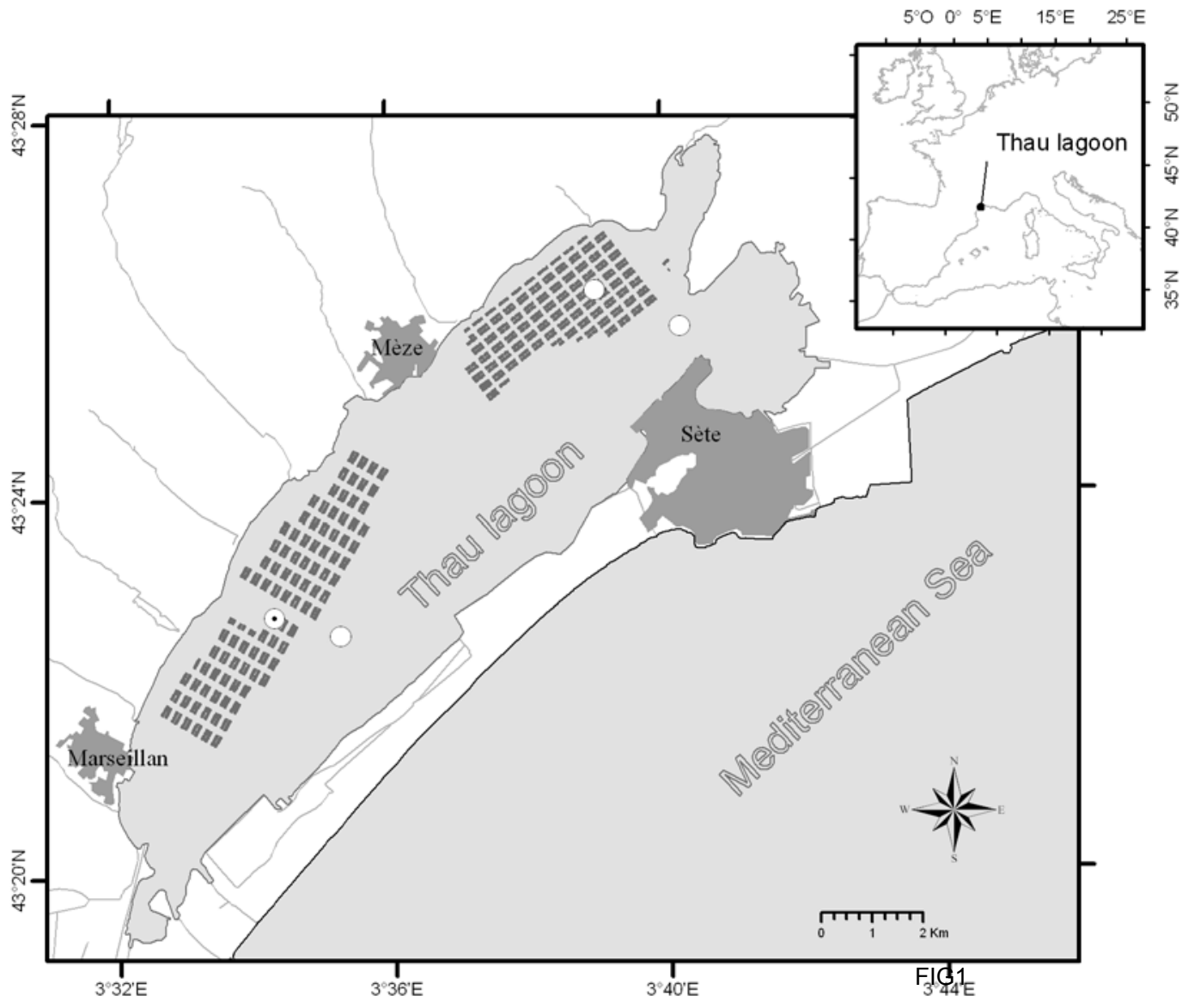



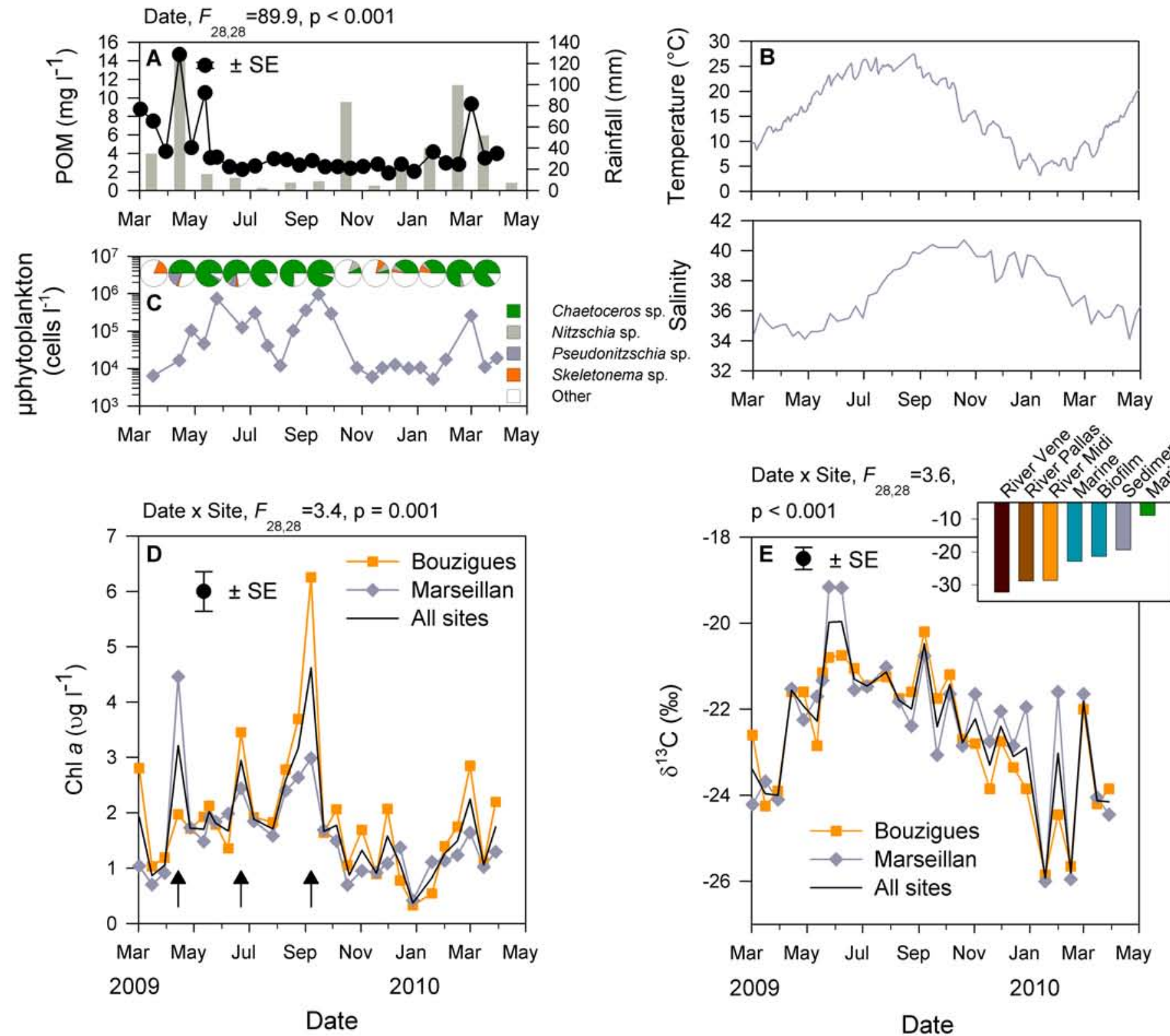

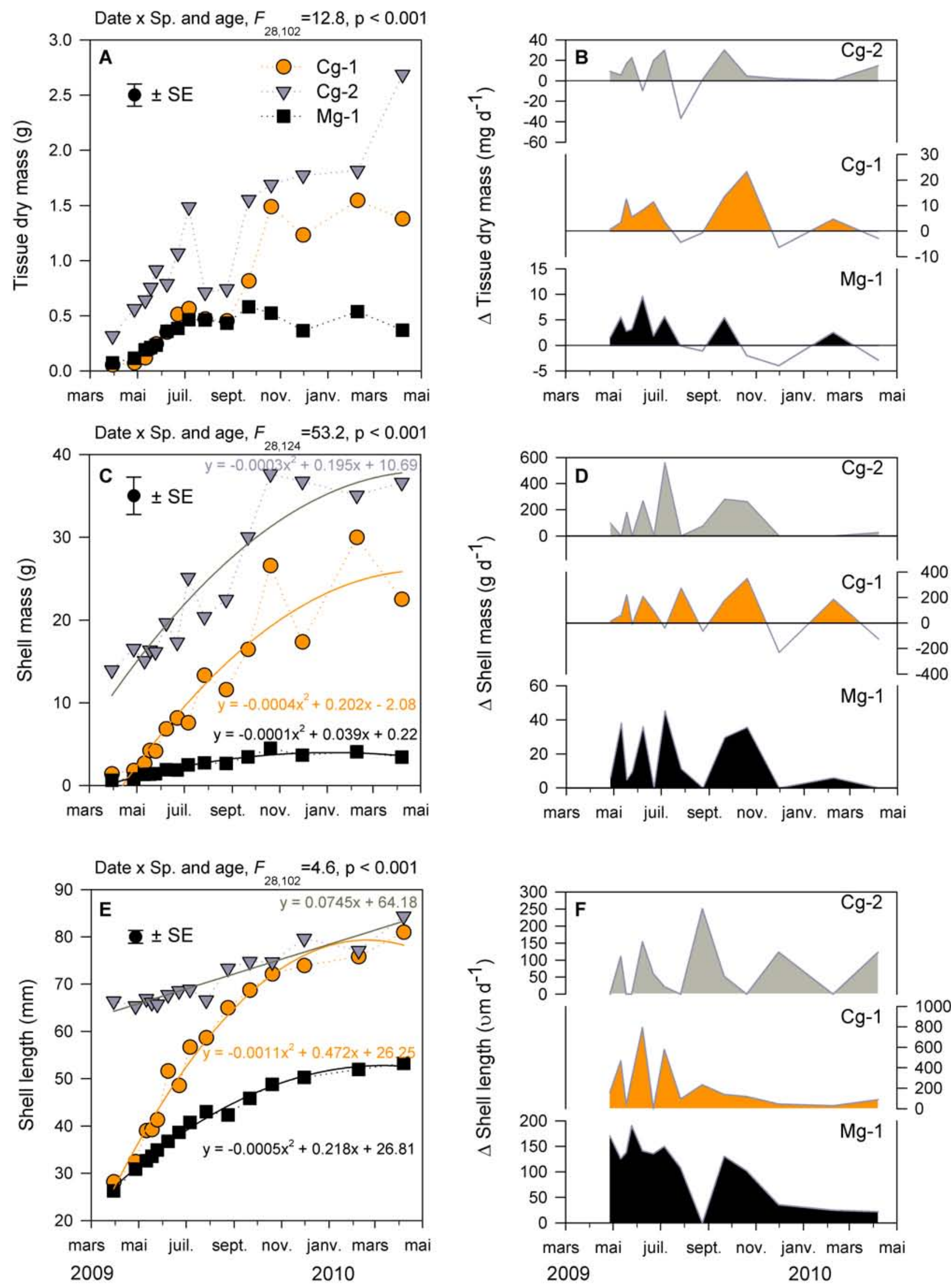

Date 


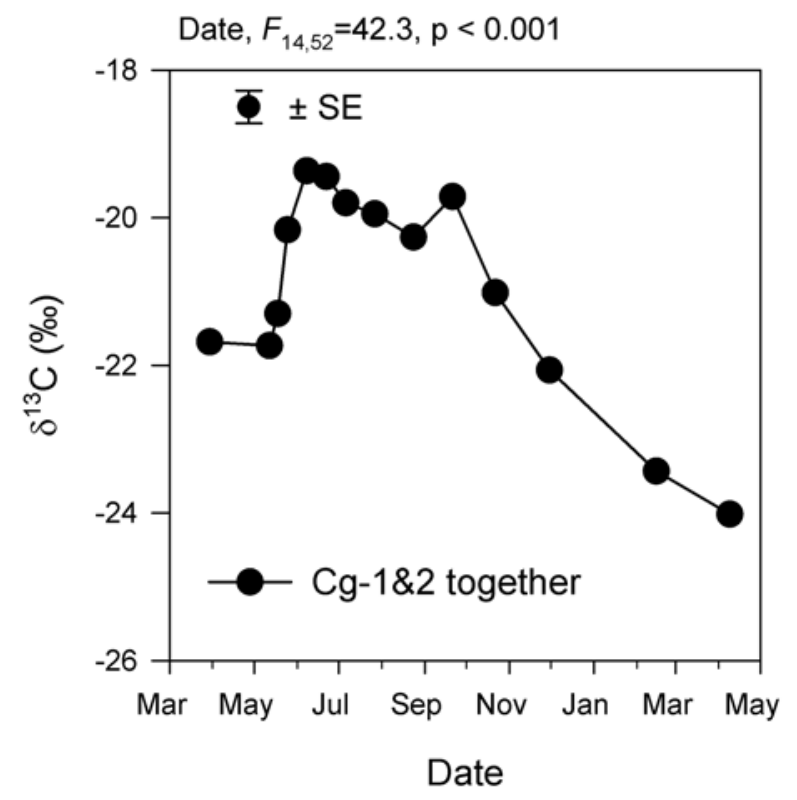




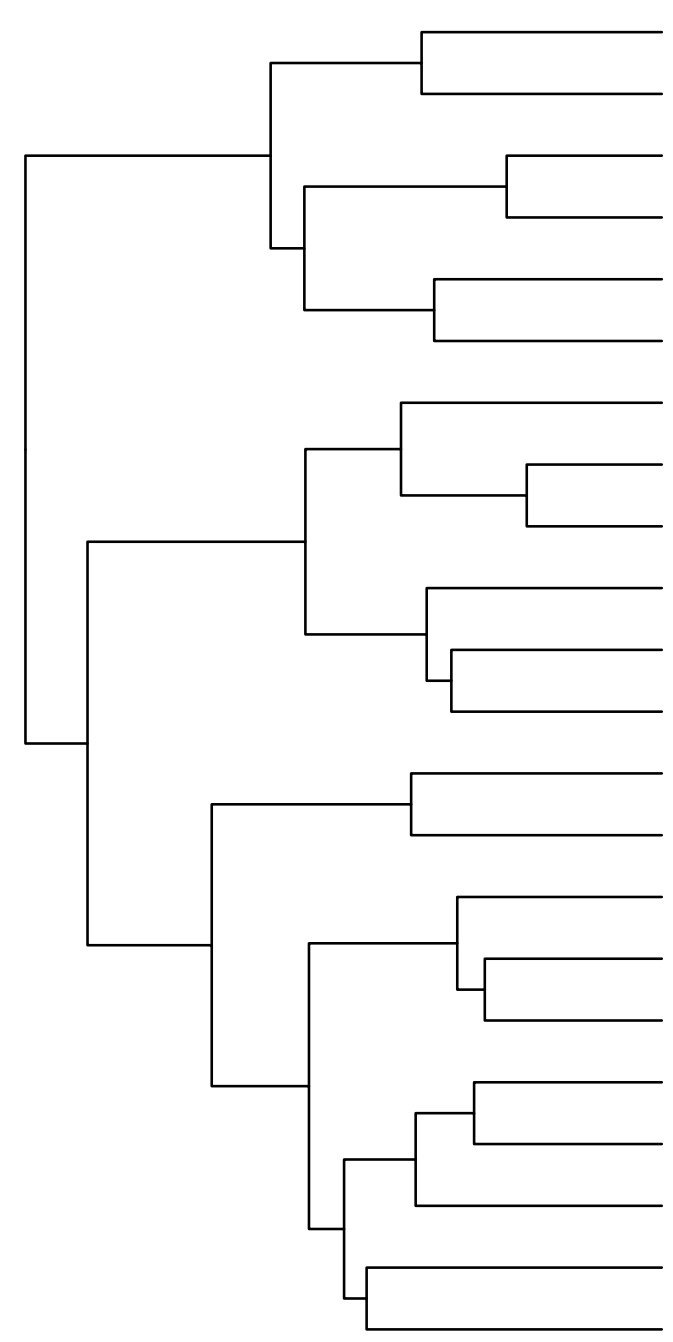

Color Key

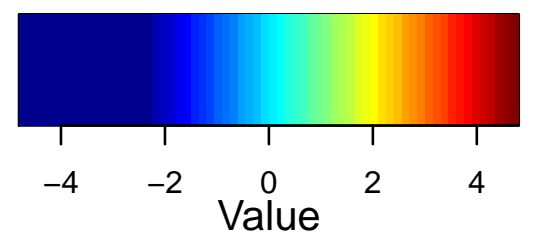

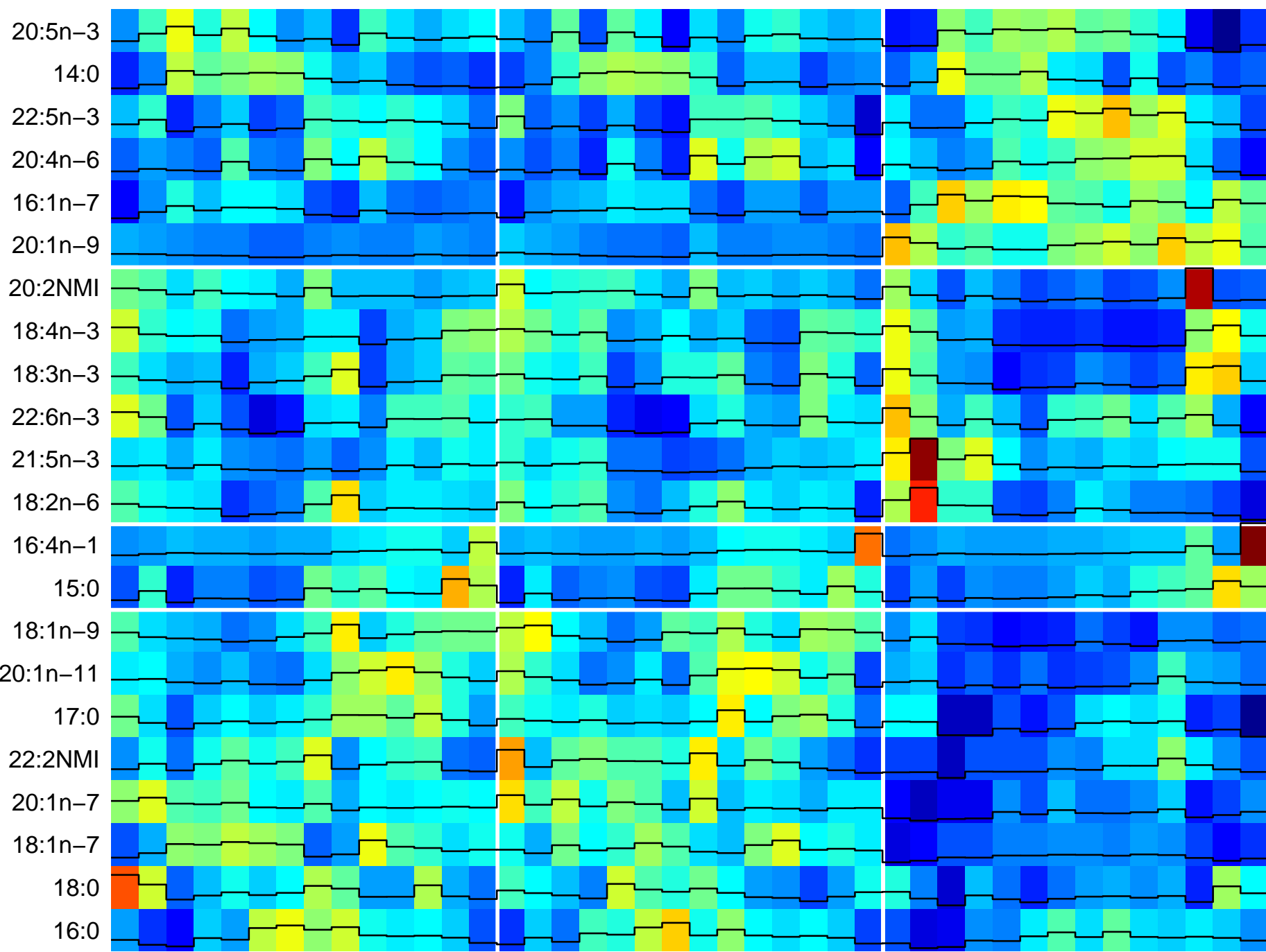

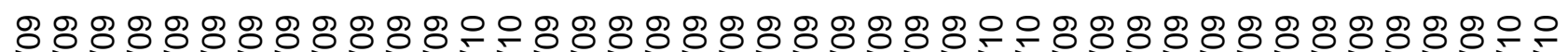

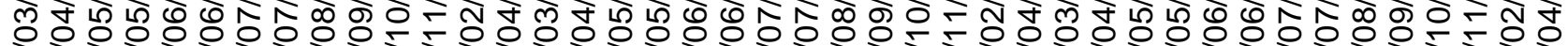

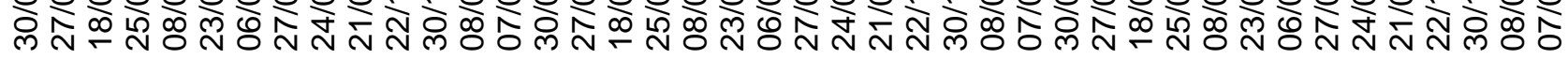

$M g-1$ 
Date $\times$ Sp. and age, $F_{26,76}=4.2, p<0.001$
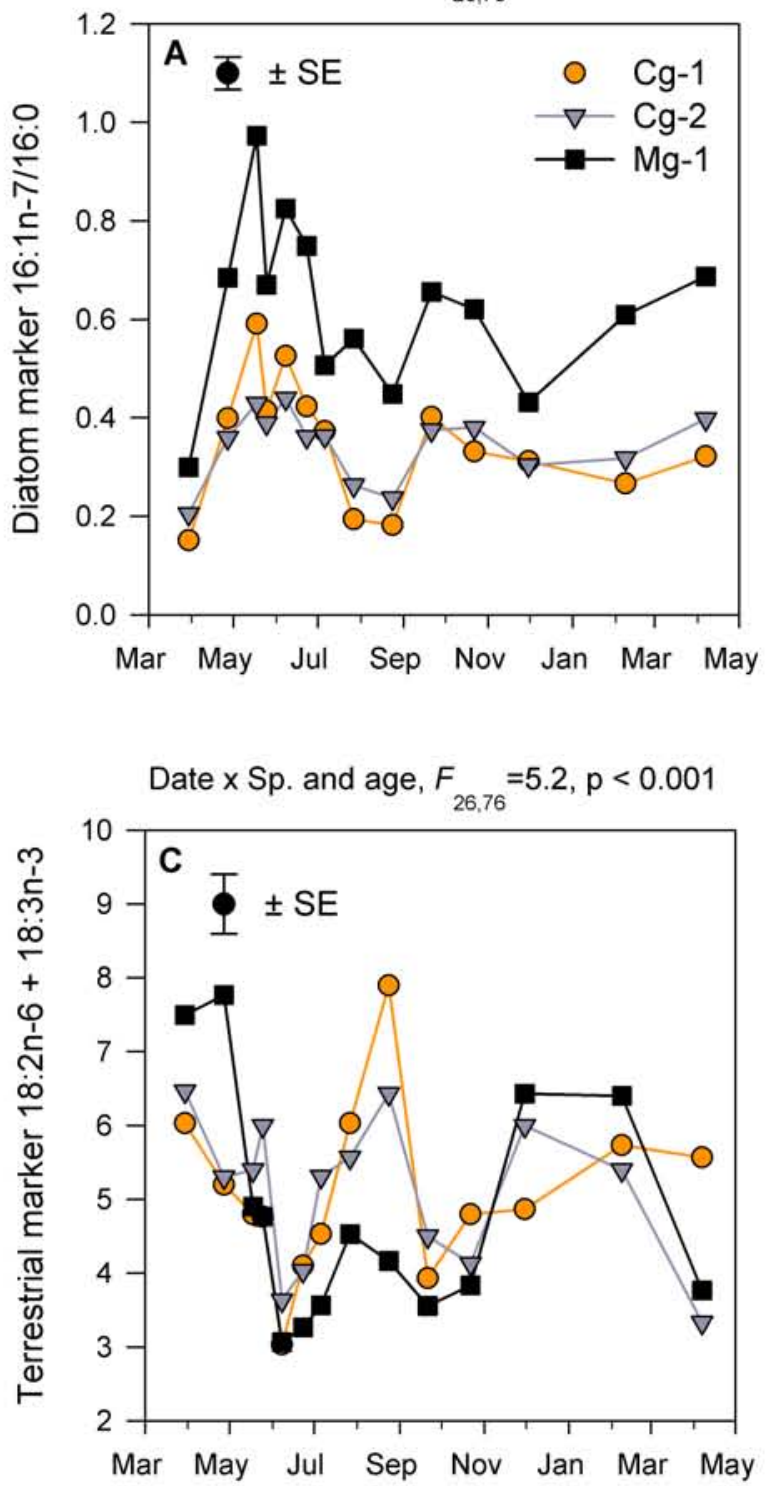

Date $\times$ Sp. and age, $F_{26,76}=2.5, p=0.001$
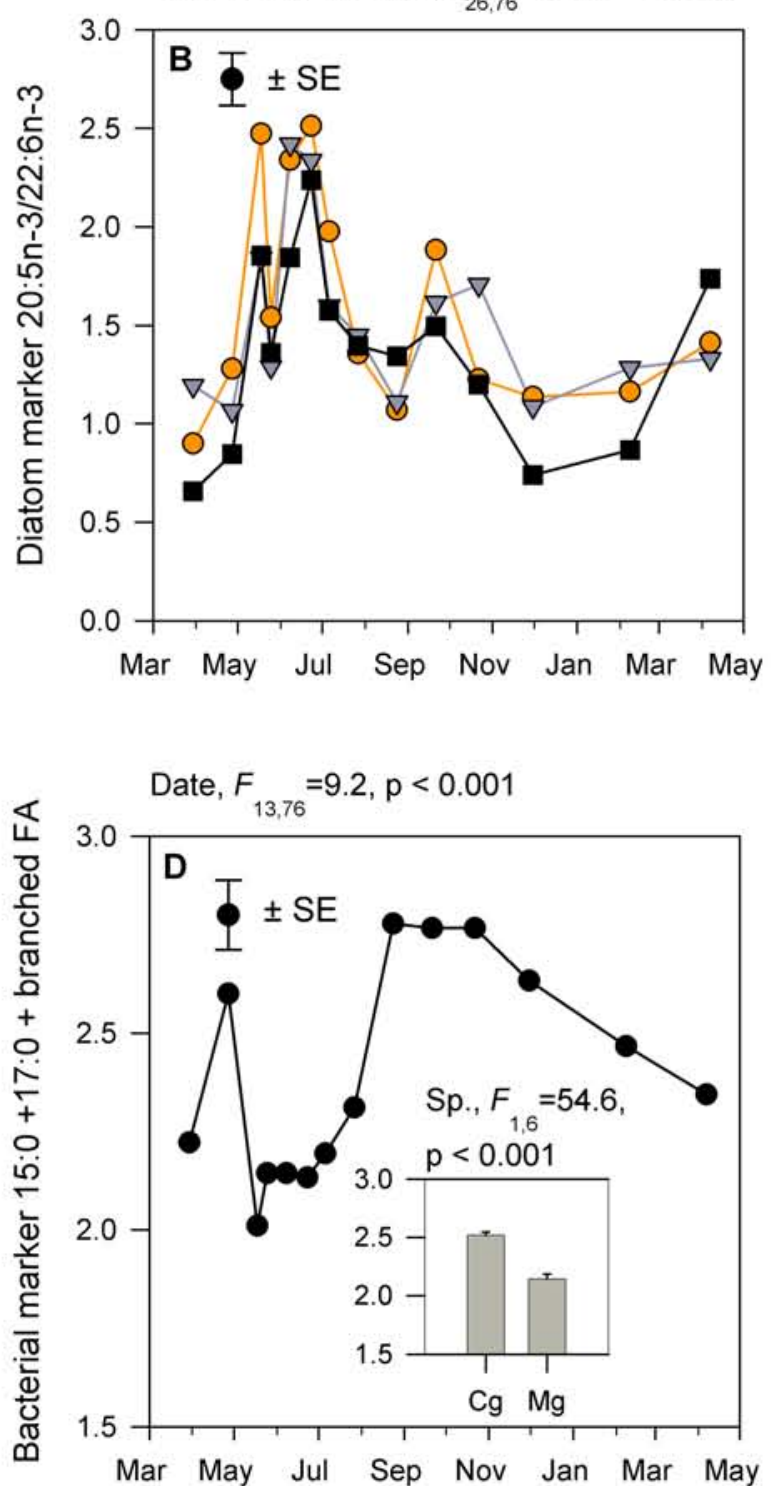

Date 